\title{
Relating structure and function of inner hair cell ribbon synapses
}

\author{
C. Wichmann • T. Moser
}

Received: 2 October 2014 / Accepted: 18 December 2014 /Published online: 22 January 2015

(C) The Author(s) 2015. This article is published with open access at Springerlink.com

\begin{abstract}
In the mammalian cochlea, sound is encoded at synapses between inner hair cells (IHCs) and type I spiral ganglion neurons (SGNs). Each SGN receives input from a single IHC ribbon-type active zone (AZ) and yet SGNs indefatigably spike up to hundreds of $\mathrm{Hz}$ to encode acoustic stimuli with submillisecond precision. Accumulating evidence indicates a highly specialized molecular composition and structure of the presynapse, adapted to suit these high functional demands. However, we are only beginning to understand key features such as stimulus-secretion coupling, exocytosis mechanisms, exo-endocytosis coupling, modes of endocytosis and vesicle reformation, as well as replenishment of the readily releasable pool. Relating structure and function has become an important avenue in addressing these points and has been applied to normal and genetically manipulated hair cell synapses. Here, we review some of the exciting new
\end{abstract}

\section{Wichmann $(\bowtie)$}

Molecular Architecture of Synapses Group, Institute for Auditory Neuroscience and InnerEarLab, University Medical Center Göttingen, Göttingen, Germany

e-mail: cwichma@gwdg.de

C. Wichmann $\cdot$ T. Moser $(\triangle)$

Collaborative Research Center 889, University Medical Center

Göttingen, Göttingen, Germany

e-mail: tmoser@gwdg.de

T. Moser

Institute for Auditory Neuroscience and InnerEarLab, University

Medical Center Göttingen, Göttingen, Germany

T. Moser

Center for Nanoscale Microscopy and Molecular Physiology of the

Brain, University of Göttingen, Göttingen, Germany

T. Moser

Bernstein Center for Computational Neuroscience, University of

Göttingen, Göttingen, Germany insights gained from recent studies of the molecular anatomy and physiology of IHC ribbon synapses.

Keywords Structure-function $\cdot$ Inner hair cells $\cdot$ Ribbon synapse $\cdot$ Exo-endocytosis $\cdot$ Otoferlin

\section{Introduction}

Synapses transfer information from sensory cells or neurons to other neurons or distinct target cell types, such as muscle cells. A plethora of presynaptic proteins orchestrate neurotransmitter release at the presynaptic active zone (AZ). These proteins are organized into three main compartments, which are ultrastructurally defined and classically referred to as (1) the cytomatrix at the active zone (CAZ) with (2) presynaptic electron dense projections that are clustering (3) synaptic vesicles (Zhai and Bellen 2004). The presynaptic dense projections appear highly variable in size and shape, which have been hypothesized to follow the function of a given synapse type. They seem to be present at all neuronal AZs but differ greatly in terms of order, density and morphology as well as molecular composition (Zhai and Bellen 2004). For example, rather small structures of less than $100 \mathrm{~nm}$ height are found at mammalian conventional central nervous system (CNS) synapses where they form a presynaptic grid, also termed a 'particle web', with a triangular or hexagonal pattern (Vrensen et al. 1980; Phillips et al. 2001; Zhai and Bellen 2004; Limbach et al. 2011; Südhof 2012). Remarkably regularly arranged structures can be observed at neuromuscular junctions of the frog (Harlow et al. 2001; Szule et al. 2012). Moreover, presynaptic dense projections are not an evolutionary invention of vertebrates, as insects such as the fruitfly Drosophila melanogaster also harbor elaborated dense projections termed 'T-bars', which 
are found at almost every synapse type (for review, see Wichmann and Sigrist 2010). The anatomical hallmark of tonically releasing sensory mammalian photoreceptor synapses, a huge plate-like dense projection that tethers hundreds of synaptic vesicles (Schmitz et al. 2000), was discovered in the 1950s (De Robertis and Franchi 1956), when transmission electron microscopy started to become a commonly used technique.

Electron microscopy allowed researchers to visualize the ultrastructure of cells in detail for the first time (De Robertis and Bennett 1955), bringing exciting new knowledge about morphology, organization and communication of cells in general and synapses in particular (see, for example: De Robertis and Bennett 1955; De Robertis and Franchi 1956). At this time, synaptic vesicles were discovered at guinea pig retinal synapses, where they were called 'minute granules' (Sjostrand 1953). Soon afterwards, the term 'synaptic vesicle' was coined by De Robertis and Bennett (1955), who were inspecting bullfrog and earthworm synapses. In parallel, the work of De Robertis and Franchi (1956) on photoreceptors of light- or dark-exposed rabbits provided the first experimental evidence correlating synaptic vesicle numbers and presynaptic activity. A few years later, the large presynaptic dense structures of these synapses were named 'ribbons', when their characteristic shape with extended longitudinal axis was recognized in serial 3D reconstructions of guinea pig retinas (Sjostrand 1958). Subsequently, synaptic ribbons were also found to decorate cochlear afferent hair cell synapses (Smith and Sjostrand 1961).

Golgi or horseradish peroxidase labeling in combination with transmission electron microscopy were also and still are, widely used to visualize neurons (Meller et al. 1968; LeVay 1973; White and Rock 1980; DeFelipe et al. 1986) and to understand the anatomy of the inner ear. For example, the afferent spiral ganglion neurons (SGNs) of the cochlear nerve, which carry the information about an acoustical signal from the inner ear to the brainstem, were studied intensely in various mammals such as guinea pig, mouse or cat (Spoendlin 1972, 1975, 1979; Paradiesgarten and Spoendlin 1976; Bodian 1978; Kiang et al. 1982; Liberman 1982a; Ginzberg and Morest 1984; Ryugo and Rouiller 1988; Liberman et al. 1990). These studies revealed that inner and outer hair cells are innervated by different SGN types (Kiang et al. 1982), outer hair cells (OHCs) by unmyelinated $(5 \%)$ and inner hair cells (IHCs) by myelinated (95\%) afferent fibers (Spoendlin 1969, 1975). Each of the myelinated, bipolar type I SGNs sends a peripheral unmyelinated and unbranched neurite to form a synapse with a single IHC ribbon synapse (Liberman 1980; Liberman et al. 1990; Buran et al. 2010; reviewed in Meyer and Moser 2010). Therefore, recordings from SGNs enable the investigation of the function of individual AZs within an IHC. Type I SGNs show different intensity thresholds and dynamic ranges in cat (Liberman and Kiang 1978). Paired recordings from hair cells and postsynaptic neurons have provided insight into synaptic sound encoding and its presynaptic determinants (Palmer and Russell 1986). Finally, observations of postsynaptic excitatory potentials by recordings from near the synapse revealed the first information on the presynaptic release mechanism (Furukawa et al. 1978; Starr and Sewell 1991; Siegel 1992). Each IHC contains 5-30 AZs, dependent on species and tonotopic position along the cochlea, generally peaking at the region with the greatest sound sensitivity for the particular species (Francis et al. 2006; Meyer et al. 2009; Meyer and Moser 2010). Liberman and co-workers were among the pioneers coupling structural investigations of the mammalian auditory system to its function. In his seminal study, Liberman's (1982b) functional characterization of cat single auditory nerve fibers was followed by horseradish peroxidase labeling to individually back-trace the innervation location at the respective IHC AZs. This approach allowed the author to relate functional parameters such as spontaneous firing rates and firing thresholds to morphology of type I SGNs, described, for example, by the dimension and location of their unmyelinated terminals on the IHCs. These studies together led to the hypothesis that ribbon synapses within a given IHC are structurally and functionally heterogeneous (which will be discussed later in this review) and pointed to the further need for detailed structure-function analyses. Horseradish peroxidase labeling combined with electron microscopy also provided insights into presynaptic vesicle cycling in hair cells (Siegel and Brownell 1986). More recently, hair cell synapses have increasingly attracted research activity and novel as well as classical methods have been employed for assessing their structure and function in combination with genetic or pharmacological manipulation of the synapses or noise exposure. Quantitative electron microscopy analysis employing electron tomography of different functional states as well as freezefracture and subsequent electron microscopy have been introduced by Roberts and others for studies of hair cell synapses (Roberts et al. 1990; Saito 1990; Lenzi et al. 1999, 2002). Molecular manipulations involving germline mutagenesis as well as virus-mediated gene transfer were established. Further, patch-clamp recordings have characterized $\mathrm{Ca}^{2+}$ currents (e.g., Lewis and Hudspeth 1983; Fuchs et al. 1990; Roberts et al. 1990; Platzer et al. 2000; Brandt et al. 2003) and membrane turnover (e.g., Parsons et al. 1994; Moser and Beutner 2000; Schnee et al. 2005) of hair cells. Technically very challenging postsynaptic patch-clamp recordings have provided insight into the excitatory postsynaptic currents (Glowatzki and Fuchs 2002) and, combined with presynaptic recordings, have elucidated hair cell synaptic mechanisms with superb resolution (e.g., Keen and Hudspeth 2006; Goutman and Glowatzki 2007; Li et al. 2009). Immunohistochemistry combined with high-resolution microscopy as well as transcriptomic and proteomic analyses have informed on the molecular composition of hair cell synapses (Khimich et al. 
2005; Uthaiah and Hudspeth 2010; Kantardzhieva et al. 2011). Finally, fluorescence imaging has been implemented for studies of hair cell synapse function (Tucker and Fettiplace 1995; Issa and Hudspeth 1996; Zenisek et al. 2003; Griesinger et al. 2005; Frank et al. 2009; Revelo et al. 2014).

Ribbon-type AZs cope with a demanding task: synaptic vesicles need to be released indefatigably and rapidly recycled at individual synapses in order to maintain high firing rates of SGNs that fire at hundreds of $\mathrm{Hz}$ even during continued stimulation (reviewed in Matthews and Fuchs 2010; Pangršič et al. 2012; Safieddine et al. 2012). Sustained exocytosis amounts to up to $70 \mathrm{~Hz}$ from each release site, of which about a dozen comprise the readily-releasable vesicle pool (RRP). This was demonstrated in mouse IHCs (Pangršič et al. 2010) and is to our knowledge one of the highest release rates per site described to date (Pangršič et al. 2012). This process requires very efficient means of clearing previously exocytosed membrane and proteins from the site followed by immobilization and priming of new vesicles for the next round of release. Moreover, the release of the neurotransmitter must exhibit both rapid ON and OFF kinetics to accurately follow acoustic stimuli with a periodicity of $1 \mathrm{~ms}$ or less (Kiang et al. 1965; Rose et al. 1967; Palmer and Russell 1986; Köppl 1997; Goutman 2012; Li et al. 2014).

How the molecular machinery of IHC AZs meets these requirements is just starting to emerge. It is becoming clear that ultrastructural assessment of functional synapse states is required in addition to the powerful combination of molecular manipulation and physiological characterization. In this review, we will emphasize recent approaches coupling functional and structural investigations of release at the level of IHCs and their ribbon synapses, as well as recent findings regarding vesicular recycling after transmitter release.

The structure of the inner hair cell is set up for efficient signaling

How does the subcellular organization of sensory IHCs enable mechanotransduction and transmitter release at high rates? IHCs are epithelial cells by origin and exhibit several characteristics that distinguish them from neurons. Most notably, they show a strong polarization with respect to both long and short cell axes. The polarization along the apicobasal axis follows a clear compartmentalization, e.g., apparent by the hair bundle harboring the mechanotransduction apparatus of the apical membrane. Graded receptor potentials are formed by mechanoelectrical (apical) and voltage-gated (basal) conductances (Corey and Hudspeth 1979; Roberts et al. 1990). Actin-filled stereocilia protrude into the endolymph in a highly organized manner and their sophisticated supramolecular mechanotransduction apparatus enables ultrasensitive detection of sound-born vibrations of the cochlear partition (reviewed in Kazmierczak and Müller 2012). While the molecular identity of the mechanotransducer channel still awaits definitive demonstration, recent work indicates the transmembrane channel-like proteins (TMC)-1 and -2 as promising candidates (Pan et al. 2013). Opening of the apical mechanotransducer channels depolarizes the IHC, subsequently activating $\mathrm{Ca}_{\mathrm{V}} 1.3 \mathrm{Ca}^{2+}$ channels (Platzer et al. 2000; Brandt et al. 2003; Dou et al. 2004) at the presynaptic AZ in the basolateral membrane, where the incoming $\mathrm{Ca}^{2+}$ triggers neurotransmitter release. The density of ribbon synapses shows a strong basoapical gradient, with the supranuclear portion of the hair cell being devoid of AZs (Francis et al. 2004; Meyer et al. 2009). In the apex, the cuticular plate likely serves as an anchor for the stereociliar actin bundles, containing a rich protein network with cytoskeletal proteins such as actin, $\alpha$-actinin and tropomyosin (Slepecky and Chamberlain 1985; Zine and Romand 1993). Moreover, the striated organelle, located underneath the cuticular plate, likely modulates the stereociliar actin bundles (Vranceanu et al. 2012). Microtubules are primarily found beneath the cuticular plate (Slepecky and Chamberlain 1985; Steyger et al. 1989; Furness et al. 1990) but appear connected to cytoskeletal proteins in the cuticular plate, for example via Acf7a (actin crosslinking family protein $7 \mathrm{a}$ ), as suggested for zebrafish neuromast hair cells (Antonellis et al. 2014). Microtubule bundles are mainly organized in the apicobasal direction (Furness et al. 1990), providing the mechanical strength of hair cells (Szarama et al. 2012) and tracks for efficient cargo protein trafficking along the apicobasal axis (Furness et al. 1990).

In addition to the cellular apicobasal polarity, hair cells also show planar cell polarity, which is reflected in the orderly orientation of their hair bundles (reviewed in Ezan and Montcouquiol 2013; Sienknecht et al. 2014). Whether the basolateral organization of the hair cells is similarly instructed by planar cell polarity remains to be tested.

In the next sections, we will focus on the organization of the basal portion of IHCs and discuss structure and function of hair cell ribbon synapses. Emphasis will be on the molecular machinery of the synapse, synapse development, synaptic heterogeneity and synaptic vesicle recycling.

\section{Molecular anatomy and physiology of hair cell ribbon synapses}

Phylogenetically, ribbons in sensory cells are old structures that occur not only in mammals but also in fishes, amphibians and birds. In the mammalian organ of Corti, they were first described by Smith and Sjöstrand (1961) and are found in both sensory cell types, i.e., IHCs and OHCs (Sobkowicz et al. 1982). The discovery of the protein RIBEYE, initially purified from bovine retina, (Schmitz et al. 2000), as the main and structure-yielding component of ribbons in rat photoreceptors (Schmitz et al. 2000), frog saccular hair cells (Zenisek et al. 2003), zebrafish photoreceptors and bipolar cells (Wan 
et al. 2005) and mouse cochlear hair cells (Khimich et al. 2005; see also immunogold labeling in Fig. 1a) highlights the conservation of the ribbon in vertebrate evolution (Schmitz 2009). Nonetheless, ribbons still vary greatly in size and shape (Lenzi and von Gersdorff 2001; Moser et al. 2006;
Matthews and Fuchs 2010), likely reflecting structural adaptation to the specific needs of the respective synaptic connection for sensory coding.

RIBEYE is composed of two major domains: while the A domain organizes the assembly of the synaptic ribbon and is
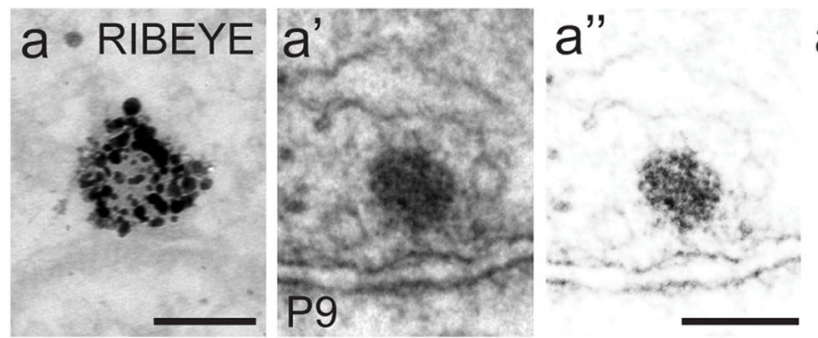

C

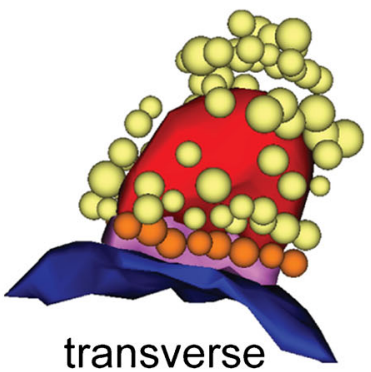

c'

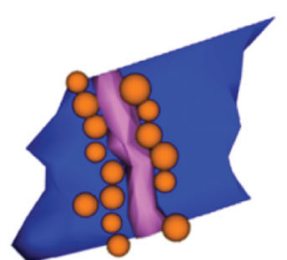

top view
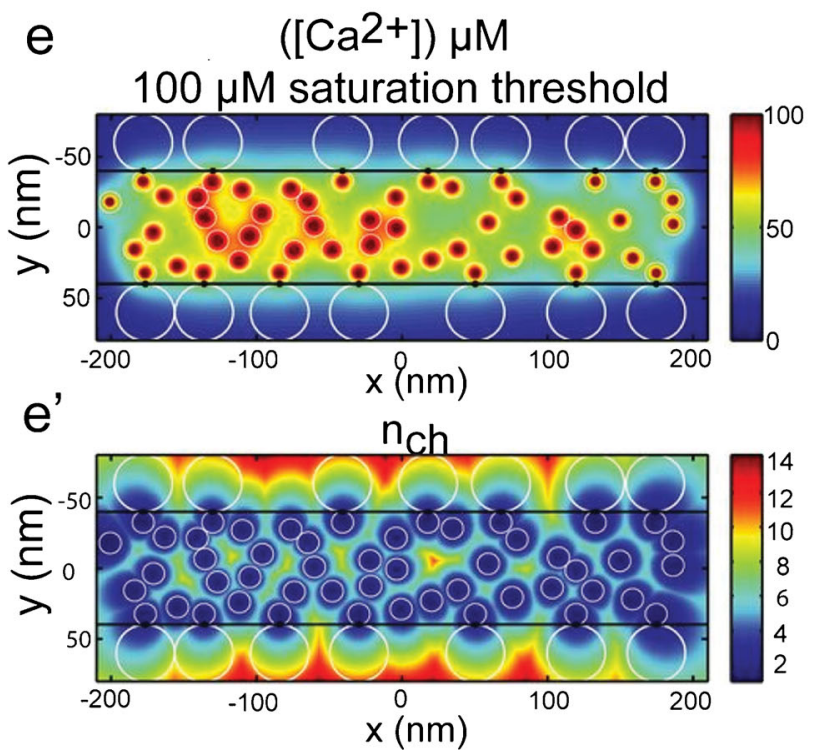

Fig. 1 Spatial distribution of IHC AZ proteins. a RIBEYE is the main component of the ribbon as shown by pre-embedding immunogold labeling of a P14 IHC synaptic ribbon using an anti-CtBP2 antibody (courtesy of Susann Michanski, InnerEarLab, University Medical Center, Göttingen, Germany); a' Representative image of an electron micrograph of a round-shaped P9 immature ribbon exhibiting a dotted pattern possibly caused by RIBEYE arrangement (contrast enhanced image in a"), see also schematic representation (a"'). b A P14 mature ribbon with the typical multi-lamellar pattern (contrast enhanced image in $\mathbf{b}$ '), see also scheme in b". Scale bars (a, a", b') $100 \mathrm{~nm}$. c A serial 3D reconstruction of a mature ribbon with two distinct morphological vesicle pools (yellow: ribbon-associated vesicles; orange: membrane-proximal vesicles; red: ribbon; blue: AZ membrane; magenta: presynaptic density). c' The membrane-proximal vesicles (orange) are arranged around the
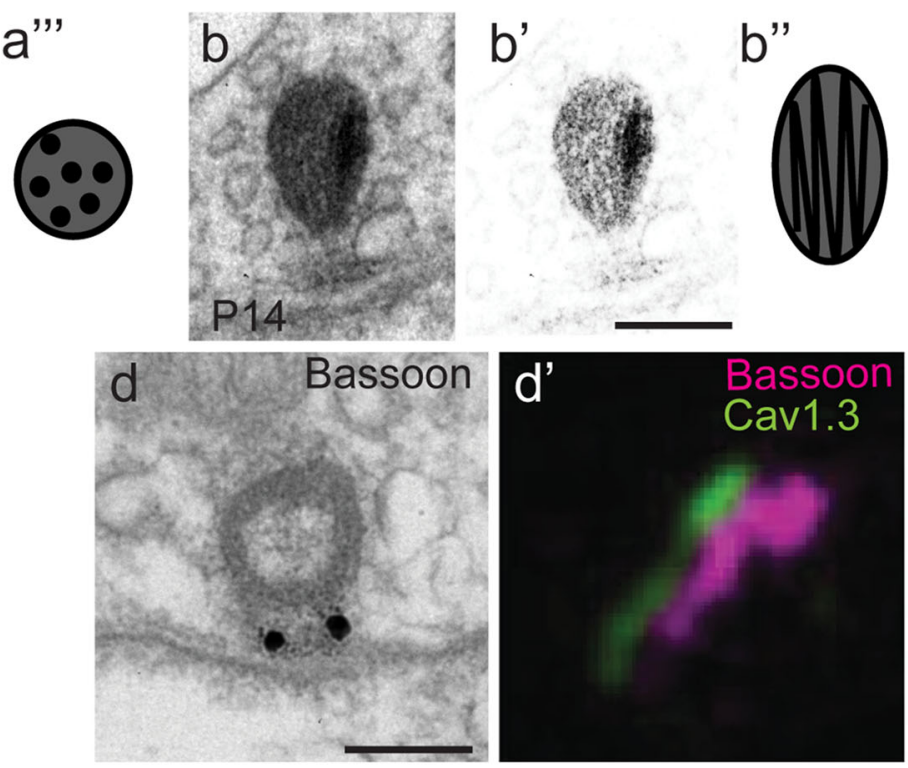

f Bassoon

Cav1.3

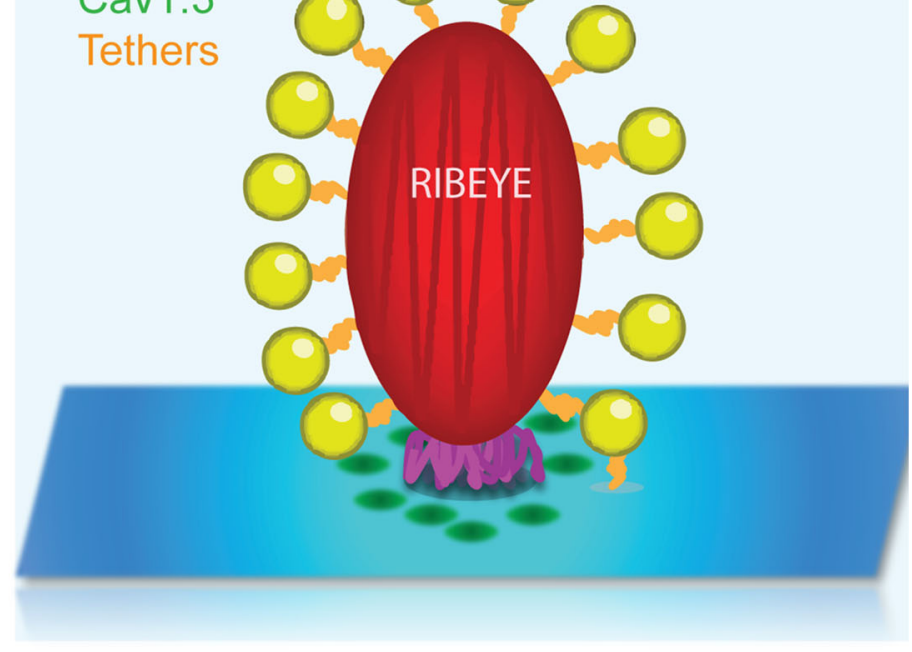

presynaptic density (magenta) that is containing the scaffolding protein bassoon as shown by the pre-embedding immunogold labeling in (d), Scale bar (d) $100 \mathrm{~nm}$ (courtesy of Susann Michanski, InnerEarLab, University Medical Center, Göttingen, Germany); d' 2-color STED image of immunolabeled bassoon (magenta) and $\mathrm{Ca}_{\mathrm{V}} 1.3$ channel clusters (green) in mature IHCs: stripe-like morphology and closely aligned immunofluorescence of bassoon and $\mathrm{Ca}_{\mathrm{V}} 1.3$ can be observed. Scale image:700× $700 \mathrm{~nm}$; e, e' Mathematic model showing the total mean steady state $\left[\mathrm{Ca}^{2+}\right]$ profile at the $\mathrm{AZ}$ membrane $(\mathbf{e})$; e' effective number of $\mathrm{Ca}_{\mathrm{V}} 1.3$ channels contributing to total mean steady state $\left[\mathrm{Ca}^{2+}\right]$ as shown in (e). (c, c', d', e, e' modified from Wong et al. 2014, EMBO J; reprinted with permission (C) 2014 Wong et al.). f Schematic summary of the protein arrangement at mature IHC ribbon synapses 
unique in structure, the B domain is structurally nearly identical to the transcription repressor $\mathrm{CtBP} 2$, which is encoded by the same gene but uses a different transcription initiation site (Schmitz et al. 2000) and exhibits enzymatic activity (Schwarz et al. 2011). The B domain is also assumed to be involved in tethering of synaptic vesicles to the ribbon (Schmitz et al. 2000; Schmitz 2009), though the proteins that form tethers remain to be identified. RIBEYE appears to organize ribbon shape directly based on its domain structure (Schmitz 2009) and its aggregation properties (Magupalli et al. 2008). A trifold lamellar pattern has been described for photoreceptor ribbons and assigned to the polarized arrangement of RIBEYE (Schmitz 2009). Also at mature IHC ribbons, a lamellar substructure is observed that harbors multiple lamellar foldings (Sobkowicz et al. 1982; Rutherford and Pangršič 2012; Fig. 1b-b") contrasting photoreceptor ribbons. This effect can be attributed to the differences in the ribbon shape in IHCs and photoreceptors. In immature IHC ribbons, the lamellar pattern is not prominent but instead a dotted pattern can be observed (Fig. 1a'-a"'). Recently, at zebrafish hair cell ribbon synapses, it was found that the RIBEYE A and B domain segregate along the vertical axis of the ribbons, with the $\mathrm{B}$ domain more located towards the basal end (Sheets et al. 2014).

RIBEYE, in contrast to other AZ proteins, is not found in invertebrates such as the fruitfly Drosophila melanogaster; however, Bruchpilot (Brp), the homolog of the vertebrate AZ protein CAST (CAZ-associated structural protein)/ERC2, functions as the main building block of T-bars (Kittel et al. 2006; Wagh et al. 2006). In fact, only the N-terminus is conserved and shows sequence homologies to CAST, whereas the C-terminus is only found in dipteran insects and rather resembles cytoskeletal elements such as plectin due to its numerous coiled-coil domains (Wagh et al. 2006). Moreover, the C-terminus mediates vesicle tethering to the T-bar (Hallermann et al. 2010).

At conventional synapses of vertebrate neurons, the structurally related proteins bassoon and piccolo as well as CAST, ELKS, rab3-interacting molecule (RIM) and Munc13 are present (Betz et al. 1998; Fenster et al. 2000; Dresbach et al. 2001; Deguchi-Tawarada et al. 2006; Wang et al. 2009; Südhof 2012). Additionally, CtBP2 and CtBP1 have also been found at conventional AZs (tom Dieck et al. 2005). Except for piccolo, which at ribbon synapses is solely expressed as a shorter splice variant nicknamed as piccolino (Regus-Leidig et al. 2013), these proteins also largely form the CAZ at photoreceptor ribbon synapses (Wang et al. 1997; tom Dieck et al. 2005; Uthaiah and Hudspeth 2010; Limbach et al. 2011; Cooper et al. 2012). The components of hair cell AZs, on the other hand, are still largely unexplored, except for bassoon (Khimich et al. 2005) and piccolo/piccolino (Khimich et al. 2005; Regus-Leidig et al. 2013). In fact, a recent study indicates that IHC synapses operate without Munc13-like priming factors (Vogl et al. 2015).

Bassoon, together with RIBEYE, is responsible for the ribbon shape and, hence, might contribute to its function.
Studies of IHCs from bassoon mutant mice indicated an anchoring function of bassoon (Khimich et al. 2005; Frank et al. 2010; Jing et al. 2013), in line with findings at photoreceptor ribbon synapses (Dick et al. 2003; tom Dieck et al. 2005). The fraction of ribbon-occupied synapses remaining in bassoondeficient IHCs seems to depend on age and residual levels of full-length bassoon (Khimich et al. 2005; Frank et al. 2010; Jing et al. 2013). In the partial deletion mutant $B s n^{\Delta E x 4 / 5}$, the fraction of ribbonless synapses increased from $50 \%$ at postnatal day 11 (P11) up to $88 \%$ at P70. A lower and relatively constant fraction of $56 \%$ ribbonless synapses was found in a gene-trap bassoon mutant $\left(B s n^{g t}\right)$ likely due to a weak residual synaptic expression of bassoon (Jing et al. 2013). However, the anchorage of the remaining ribbons seems impaired (Frank et al. 2010; Jing et al. 2013). In line with a better maintained AZ ultrastructure, $B s n^{g t}$ animals exhibited a larger number of $\mathrm{Ca}^{2+}$ channels at IHC synapses compared to $B s n^{\Delta E \times 4 / 5}$ mice and also displayed an intermediate phenotype regarding sustained IHC exocytosis (Jing et al. 2013). In contrast, the size of the readily releasable vesicle pool (RRP) was strikingly reduced in both mutants. Moreover, single unit recordings of the SGNs show comparably severe defects in $B s n^{g t}$ and $B s n^{\Delta E x 4 / 5}$ mice, as both genotypes had impaired sound onset coding and lower evoked and spontaneous spike rates. Taken together, these results indicate that the remaining, loosely anchored ribbons might function inadequately (Jing et al. 2013). This further suggests that the mere presence of the ribbon, even with tethered vesicles, is not sufficient to maintain normal transmitter release and sustain the RRP at IHC ribbon synapses. Moreover, it seems that bassoon contributes to organizing the IHC AZ beyond anchoring the ribbon. This has been concluded from impaired clustering of $\mathrm{Ca}^{2+}$ channels at $B s n^{\Delta E x 4 / 5}$ ribbon-occupied synapses (Frank et al. 2010) and indicates a potential direct contribution of bassoon in organizing the AZ (Frank et al. 2010; Hallermann and Silver 2013).

In contrast to conventional synapses, where often only the combined knockdown of bassoon and its homolog piccolo causes synaptic defects (Altrock et al. 2003; Leal-Ortiz et al. 2008; Mukherjee et al. 2010; Waites et al. 2011, 2013), these proteins seem not to act redundantly at ribbon synapses. As mentioned above, at hair cell and photoreceptor ribbons, only the short isoform of piccolo, piccolino, is expressed, which lacks a large C-terminal part (Regus-Leidig et al. 2013, 2014). Binding sites for the proteins Abp1, Pra1, GIT1 and profilin (Wang et al. 1999; Fenster et al. 2000, 2003; Kim et al. 2003) are still present, whereas binding sites for, e.g., bassoon or RIM are lacking (Regus-Leidig et al. 2013). Therefore, different functions of piccolino and bassoon at ribbons synapses can be assumed. Accordingly, piccolino exhibits a different spatial distribution at ribbon synapses of photoreceptors, where it is found directly on the ribbon, as indicated by pre-embedding immunogold-labelings, using an antibody recognizing the N- 
terminus of the protein (Limbach et al. 2011; Dick et al. 2001). Furthermore, a recent study by Regus-Leidig et al. (2014) revealed a striking impairment in the ribbon structure upon piccolino RNAi-based knockdown. After piccolino knockdown, the typical plate-like structure failed to form properly. Instead, a high proportion of attached spherical ribbons was found that resemble ribbon precursors of photoreceptor ribbons suggesting a role of piccolino in structural ribbon maturation (Regus-Leidig et al. 2014). Taken together, RIBEYE and presumably piccolino as well as bassoon present the main structural components of the ribbon and/or the anchorage of the ribbon to the AZ.

In order to resolve the function of ribbons, several hypotheses have been put forward. The ribbon was suggested to (1) promote a large readily releasable pool of vesicles via establishing/ stabilizing many $\mathrm{Ca}^{2+}$ channels and vesicular release sites (Khimich et al. 2005; Frank et al. 2010), (2) facilitate vesicle replenishment at the AZ (conveyor belt model, e.g., Bunt 1971; Gray and Pease 1971; Vollrath and Spiwoks-Becker 1996; Lenzi and von Gersdorff 2001; Snellman et al. 2011), (3) facilitate multivesicular release (Edmonds 2004; Fuchs 2005), or (4) serve as a diffusion barrier to enable high local $\mathrm{Ca}^{2+}$ concentrations (Graydon et al. 2011). Functional interpretations have also been provided for the morphologically distinct populations of synaptic vesicles at ribbon synapses but in each case remain to be validated. Ribbon-associated vesicles - structurally attached through filamentous protein tethers - form a halo around the ribbon (Fig. 1b, c). The ones at the base of the ribbon face the presynaptic plasma membrane (membrane-proximal vesicles; Fig. 1c, c') and are often tethered to the membrane and/or to the presynaptic density (tethered vesicles). Lateral to this subpopulation of ribbon-associated vesicles, there are few additional membrane-proximal and even membrane-tethered vesicles that are not in close vicinity to the ribbon. While further testing is required, current evidence suggests that the membraneproximal vesicles comprise the RRP (e.g., in retinal bipolar cells: von Gersdorff et al. 1996; Zenisek et al. 2000; frog saccular hair cells: Lenzi et al. 1999, 2002; Rutherford and Roberts 2006; and mouse inner hair cells: Khimich et al. 2005; Frank et al. 2010; Wong et al. 2014). Support for this hypothesis comes from the approximate matching between the morphologically estimated number of membrane-proximal vesicles and the functionally defined size of the RRP, i.e., the fast component of exocytosis upon depolarization-evoked $\mathrm{Ca}^{2+}$ influx (von Gersdorff et al. 1996; Pangršič et al. 2010; Frank et al. 2010), as well as from the observation that these vesicles are most heavily depleted upon stimulation (Lenzi et al. 2002; Pangršič et al. 2010). Furthermore, the tethering of vesicles to the AZ membrane might reflect a structural correlate of fusion competence (Siksou et al. 2009; Frank et al. 2010; Fernández-Busnadiego et al. 2013). New high-resolution imaging approaches using rapid freezing methods and/or electron tomography have revealed that synaptic vesicles in proximity to the membrane exhibit several morphologically distinct stages. Tethers of different numbers and lengths connecting synaptic vesicles to the $\mathrm{AZ}$ membrane could be observed at conventional synapses and synaptosome preparations (Siksou et al. 2007, 2009; FernándezBusnadiego et al. 2010, 2013) but also at IHC ribbon synapses (Frank et al. 2010). Moreover, cryo-electron tomography, a method allowing visualization of hydrated and unstained tissue, revealed that tethering of synaptic vesicles in synaptosomes prepared from hippocampal tissue precedes the full contact of a synaptic vesicle with the membrane (Fernández-Busnadiego et al. 2010). In this process, single long tethers initially seem to be formed and synaptic vesicles likely enter the RRP via the formation of several short tethers $(<5 \mathrm{~nm})$. In line with this hypothesis, this fraction of vesicles could be depleted by application of hypertonic sucrose, that is thought to trigger RRP release (Rosenmund and Stevens 1996). Moreover, the formation of short tethers could be inhibited using tetanus toxin, pointing towards the fact that neuronal soluble NSF attachment protein receptors (SNARE) proteins are involved in this process (Fernández-Busnadiego et al. 2010). The priming factors Munc13-1 (Betz et al. 2001; Siksou et al. 2009; FernándezBusnadiego et al. 2013) and RIM1 $\alpha$ (Fernández-Busnadiego et al. 2013) play a crucial role in tethering vesicles to the membrane at conventional CNS synapses. Interestingly, Munc13 and CAPS priming factors seem not to operate at the IHC ribbon synapse (Vogl et al. 2015). Some authors even argue that the entire ribbon-associated vesicle population is fusioncompetent and, therefore, can be released within a few milliseconds or less (Heidelberger et al. 1994; Edmonds 2004). Evidence for a priming function of the ribbon has recently been presented (Snellman et al. 2011).

In contrast to CAZ proteins, which are, at least in part, conserved at IHC AZs, the molecular machinery involved in the regulation of synaptic vesicle fusion seems to deviate strongly from that of 'conventional' CNS synapses.

As mentioned above, neurotransmitter release at conventional synapses is mediated by neuronal SNAREs, namely SNAP-25, syntaxin 1 and synaptobrevin 1 or 2 (reviewed in Jahn and Fasshauer 2012). SNARE activity can be blocked by neurotoxin-mediated cleavage or genetic manipulations (Schiavo et al. 1992, 2000; Nouvian et al. 2011). At photoreceptor ribbon synapses, the SNARE protein machinery appears to be present and functional (Brandstätter et al. 1996; Morgans et al. 1996; Morgans 2000; von Kriegstein and Schmitz 2003; Uthaiah and Hudspeth 2010; Cooper et al. 2012). In contrast, IHC exocytosis seems to be insensitive to neurotoxins and genetic ablation of neuronal SNAREs (Nouvian et al. 2011) and, hence, a functional role of syntaxin 1 , synaptobrevin 1 and 2 as well as SNAP-25 in IHC exocytosis is questionable. While some studies detected SNARE mRNAs and proteins in the sensory epithelium and hair cells (Safieddine and Wenthold 1999; Uthaiah and Hudspeth 2010; Nouvian et al. 2011), neither SNAP-25, synaptobrevin 1-3 nor syntaxin 1 could be 
detected by immunofluorescence imaging in mouse IHCs (Nouvian et al. 2011). Moreover, SNARE regulators such as synaptotagmins 1-3 (Beurg et al. 2010; Reisinger et al. 2011) and complexins (Strenzke et al. 2009; Uthaiah and Hudspeth 2010) appear to be absent from mature IHCs. In contrast, the multi- $\mathrm{C}_{2}$ domain protein otoferlin plays a central role for hair cell exocytosis (Roux et al. 2006; Beurg et al. 2008; Dulon et al. 2009; Pangršič et al. 2010).

The absence or mutation of otoferlin causes deafness or temperature-sensitive hearing impairment in humans (Yasunaga et al. 1999; Varga et al. 2006; RodríguezBallesteros et al. 2008) and rodents (Roux et al. 2006; LongoGuess et al. 2007; Schwander et al. 2007). Ultrastructurally, otoferlin is also found at ribbon synapses, mostly but not exclusively at synaptic vesicles and the AZ membrane (Roux et al. 2006). Sufficient amounts of otoferlin appear to be required for correct vesicular fusion and replenishment (Roux et al. 2006; Pangršič et al. 2010, 2012). Otoferlin is suggested to act as the $\mathrm{Ca}^{2+}$ sensor in IHCs (Roux et al. 2006; Johnson and Chapman 2010), due to its $\mathrm{Ca}^{2+}$-binding capabilities (Roux et al. 2006; Ramakrishnan et al. 2009, 2014; Johnson and Chapman 2010; Pangršič et al. 2010) and facilitates SNARE-mediated liposome fusion (Johnson and Chapman 2010). In its absence, no depolarization-evoked RRP exocytosis is observed in IHCs (Roux et al. 2006; Pangršič et al. 2010). Transgenic expression of synaptotagmin 1 , the major $\mathrm{Ca}^{2+}$ sensor of neuronal synaptic vesicle exocytosis, failed to restore IHC exocytosis and hearing in otoferlin $\mathrm{KO}$ mice, which may not be too surprising given the overall low conservation of the molecular composition between conventional and IHC synapses (Reisinger et al. 2011).

Next to proteinaceous exocytosis machineries, the actual mechanisms of vesicle fusion as well as the transport of vesicles to the IHC release site are still largely unknown. The large and, in terms of amplitude and shape, heterogeneous excitatory postsynaptic currents (EPSCs) measured at postsynaptic afferent boutons of SGNs have been interpreted to result from multivesicular (multiquantal) release at IHC AZs (Glowatzki and Fuchs 2002). Large EPSCs ensure rapid and temporal precise spike generation of SGNs (Rutherford et al. 2012) and the relevance of such large EPSCs for achieving a high synchronization index of postsynaptic firing (i.e., better phase locking precision) has recently been shown in the frog papilla (Li et al. 2014).

Several multiquantal release scenarios at IHC ribbons have been discussed: (1) synchronized vesicle fusion of several single vesicles as well as (2) compound fusion, following homotypic vesicle-to-vesicle fusion and (3) sequential fusion involving homotypic vesicle-to-vesicle fusion while release occurs (Glowatzki and Fuchs 2002; Edmonds 2004; Neef et al. 2007). Recent findings suggest an alternative candidate mechanism for IHC exocytosis. Combining experimental approaches and mathematical modeling Chapochnikov et al. (2014) indicated that univesicular (uniquantal) release can explain the large size of SGN EPSCs and that the control of release by a dynamic vesicular fusion pore can account for the observed EPSC heterogeneity. At this point, none of the above discussed mechanisms can definitively be ruled out or confirmed and future work, including detailed morphological analysis using electron microscopy of defined functional states, will be required to advance our understanding of exocytosis mechanism at IHC ribbon synapses.

In case vesicles do not homotypically fuse with other vesicles at the ribbon while releasing, a transport mechanism of the vesicles to the membrane has to exist. The conveyor belt model, transporting the vesicle actively along the ribbon to the membrane, was one of the first models to be introduced (Bunt 1971; Gray and Pease 1971; Vollrath and Spiwoks-Becker 1996; Lenzi and von Gersdorff 2001). Accordingly, a kinesin polypeptide, Kif3a, was identified on photoreceptor ribbons that could serve as a motor for vesicle transport involving the filamentous tethers observed at the ribbon (Muresan et al. 1999), which were also proposed to function as 'stepping stones' for synaptic vesicles (Usukura and Yamada 1987; Parsons and Sterling 2003). Recently, the tethers at the ribbon were suggested to be directly involved in coordinating vesicle transport towards the membrane via 'crowd surfing', based on passive diffusion following the gradient established by exocytic vesicle consumption at the base of the ribbon (Graydon et al. 2014). In this model, the tethers simply need to bind the vesicles and prevent them from detaching until they reach the AZ membrane, where release maintains the diffusion gradient (Graydon et al. 2014). However, future experiments involving mutant analyses will be necessary to identify the proteins mediating vesicular tethering to the ribbon and estimate their affinity to the vesicles and the functional relevance of the tethers for synaptic transmission. Moreover, it will be interesting to investigate whether and how the tethering can be influenced by factors such as activity or even developmental stage. For example, maturation from pre-hearing to hearing significantly determines structure and function of the ribbon synapses and the spatial arrangement of $\mathrm{AZ}$ proteins such as the $\mathrm{Ca}^{2+}$ channels or bassoon, as will be emphasized in the next section.

Structural and functional maturation of inner hair cell ribbon synapses

During maturation of the organ of Corti, ribbon synapses and SGN fibers undergo drastic morphological changes. How do morphological alterations during the transition from a prehearing to a hearing state correlate to functional maturation of ribbon synapses? Generally, synaptic contacts are ultrastructurally defined as pre- and postsynaptic electron-dense membranes that are closely aligned. The postsynaptic density (PSD) is clearly visible as an electron-dense structure beneath the postsynaptic membranes directly juxtaposed to the 
presynaptic AZ. The innervation pattern of SGN fibers at hair cells within the immature rodent cochlea is significantly different from the mature configuration and massive rearrangements of the fibers that occur before the onset of hearing. Hereby, type I SGN fibers retract from the OHCs, whereas type II SGN fibers disappear from the IHCs (Perkins and Morest 1975; Echteler 1992; Simmons 2002). These developmental processes of fiber innervation take place in the first postnatal week in three distinct phases: (1) in E18-P0 animals, fibers of both afferent types extend towards all hair cells; (2) between $\mathrm{P} 0$ and $\mathrm{P} 3$ a refinement occurs, where the outer spiral bundle forms that innervate the $\mathrm{OHCs}$; and (3) the type I fibers retract from the OHCs around P3-P6, accompanied by synaptic pruning, while they keep their projections on the IHCs (Huang et al. 2007). In line with SGN fiber type I retraction, AMPA-typed glutamate receptors and scaffold proteins like bassoon and shank1 disappear during the maturation process from OHCs. In contrast, at IHC afferent PSDs AMPAreceptors persist. GluA2/3 subunits remain stable throughout development and into adulthood, while GluA4 subunit expression significantly increase in adult type I fibers (Huang et al. 2012).

Recently, the molecular arrangement of afferent synapses in relation to functional changes at the IHCs has been addressed in more detail using a combination of confocal, stimulated emission depletion (STED) and electron microscopy, as well as IHC presynaptic physiology and computational modeling (Wong et al. 2014). It is known that, in the early pre-hearing stages between P6 and P9, several small apposing pre- and postsynaptic densities mark nascent synapses. Some of the presynaptic densities are occupied by synaptic ribbons, which are small and round in shape and attached via two triangular-shaped proteinaceous anchors (Sobkowicz et al. 1982; Wong et al. 2014). However, floating ribbons were also frequently observed in close proximity to $\mathrm{AZ}$ areas at these developmental stages (Wong et al. 2014). Serial 3D electron microscopic reconstructions corroborated the notion of several discontinuous pre- and postsynaptic specializations. Such synaptic sites are organized as loose suprastructures on the bouton surface and are likely functional, as immunohistochemistry indicates the presence of presynaptic $\mathrm{Ca}^{2+}$ channels and postsynaptic AMPA receptors (Wong et al. 2014). STED microscopy, which enables resolution below the diffraction limit (Klar et al. 2000; Hell 2007), revealed that $\mathrm{Ca}_{\mathrm{V}} 1.3$ channels are arranged in small round spots (Wong et al. 2014) rather than the stripes previously described for mature AZs (Frank et al. 2010; see also Fig. 1d'). In addition, a huge number of extrasynaptic $\mathrm{Ca}_{\mathrm{V}} 1.3$ channels can be observed in immature IHCs (Zampini et al. 2010; Wong et al. 2014), which enable the cells to fire $\mathrm{Ca}^{2+}$ action potentials (Kros et al. 1998; Brandt et al. 2003). These action potentials evoke exocytosis in the pre-hearing stage (Beutner and Moser 2001; Glowatzki and Fuchs 2002; Johnson et al. 2005) but show lower ' $\mathrm{Ca}^{2+}$ efficiency' (Beutner and Moser 2001; Brandt et al. 2003; Johnson et al. 2005) and a supra-linear $\mathrm{Ca}^{2+}$ dependence (Johnson et al. 2005). The pre-sensory IHC activity appears to drive bursting activity in the developing auditory system (Glowatzki and Fuchs 2002; Tritsch et al. 2007, 2010; Wong et al. 2013; Clause et al. 2014). In this context, the regulation of presynaptic firing by paracrine and/or efferent synaptic control is being subject to intense research (Glowatzki and Fuchs 2000; Tritsch et al. 2007; Johnson et al. 2011; Sendin et al. 2014). Efferent innervation, moreover, seems to play an important role in the maturation process of IHCs (Glowatzki and Fuchs 2000; Marcotti 2004; Goutman et al. 2005). Efferent fibers originate from the superior olivary complex and, before onset of hearing, form transient axosomatic contacts with IHCs (Simmons et al. 1996; Katz et al. 2004). Later, they largely retract from IHCs and rather form axodendritic contacts to the afferent terminals (Pujol et al. 1998). The transient efferent inhibition is thought to counteract the IHC depolarization resulting from the resting mechanotransducer current (Géléoc and Holt 2003; Waguespack et al. 2007; Lelli et al. 2009). Upon genetically induced impairment of the efferent input, the linearization of $\mathrm{Ca}^{2+}$ dependent exocytosis is affected (Johnson et al. 2007) and the maturation of IHC afferent synapses is also disturbed (Johnson et al. 2013b). Around the onset of hearing (at around P11; Mikaelian and Ruben 1965), when graded receptor potentials start governing transmitter release, extrasynaptic $\mathrm{Ca}_{\mathrm{V}} 1.3$ channels get pruned and spatial coupling of $\mathrm{Ca}^{2+}$ channels and vesicular release sites is tightened. This leads to an increase of the ' $\mathrm{Ca}^{2+}$ efficiency' of exocytosis and a near-linear $\mathrm{Ca}^{2+}$ dependence of RRP exocytosis when probed with changes in the number of open $\mathrm{Ca}^{2+}$ channels (Wong et al. 2014). Therefore, while the intrinsic $\mathrm{Ca}^{2+}$ dependence of exocytosis apparently does not change upon the onset of hearing, experimental data and biophysical modeling of exocytosis at mature and immature AZ topographies support the notion of a developmental switch from the more ' $\mathrm{Ca}^{2+}$ microdomain-like control' of exocytosis by several $\mathrm{Ca}^{2+}$ channels per vesicle to a more ' $\mathrm{Ca}^{2+}$ nanodomain-like control of exocytosis' (Wong et al. 2014; Fig. 1e, e'). Interestingly, in adult gerbils, the open probability of $\mathrm{Ca}^{2+}$ channels in IHCs increased due to a preference of the $\mathrm{Ca}^{2+}$ channel for the bursting mode (Zampini et al. 2013).

Structurally, alongside $\mathrm{Ca}^{2+}$ channels, other presynaptic $\mathrm{AZ}$ components become reorganized such as the bassoon containing presynaptic density (Fig. 1d). These alterations are accompanied by changes of the postsynaptic glutamate receptor fields that also develop to one continuous ring-like cluster (Wong et al. 2014). Moreover, ribbons increase in size and undergo striking changes of shape. At the ultrastructural level, their cross-sectional shape changes from predominantly round (Fig. 1a') to a rather oval-, droplet- or wedge-like shape between P14 and P20 (Wong et al. 2014; Fig. 1b) and ribbon 
architecture extends in the longitudinal direction (Sobkowicz et al. 1982; Wong et al. 2014) likely by gaining additional ribbon material. The two rootlets seem to merge to a continuous presynaptic density that contains the scaffolding protein bassoon, as revealed by immunogold labeling (Wong et al. 2014; Fig. 1d). Shortly after onset of hearing at P14, a large proportion of ribbons with two rootlets can still be found, whereas about a week later the morphological maturation appears to be completed (Wong et al. 2014, see, for summary, Fig. 1f). Factors that participate in the maturation of IHC synapses, next to the efferent olivocochlear transmission (see above; Johnson et al. 2013a), are thyroid hormone (Sendin et al. 2007) and myosin 6 (Heidrych et al. 2009; Roux et al. 2009). For both, a higher proportion of morphological immature ribbons have been observed in genetic deletion models.

In conclusion, during development from pre-hearing to hearing, IHC ribbon synapses undergo major morphological and functional refinements, resulting in tighter spatial coupling between $\mathrm{Ca}^{2+}$ influx and exocytosis (Wong et al. 2014).

\section{Dynamics and heterogeneity of hair cell ribbon synapses}

The number of $\mathrm{Ca}^{2+}$ channels, vesicular release sites and ribbon-associated vesicles seems to scale with the size and number of ribbons at the AZ (Martinez-Dunst et al. 1997; Frank et al. 2009; Graydon et al. 2011; Kantardzhieva et al. 2013; Wong et al. 2013, 2014). Strengthening of presynaptic transmitter release might therefore be accomplished by increasing ribbon or $\mathrm{AZ}$ size and/or ribbon numbers per $\mathrm{AZ}$. Moreover, synaptic strength might be determined by the amount and distribution of postsynaptic AMPA receptors. Finally, lateral olivocochlear efferent fibers might modulate postsynaptic excitability and thereby affect afferent synaptic strength. To establish which of these mechanisms contribute to determining and regulating synaptic strength of hair cell synapses awaits further structural and functional characterization.

Interestingly, the size and shape of ribbons appear to be highly variable and dynamic. In fact, in photoreceptors, these parameters strongly correlate with activity in light (silent) or dark (active) conditions (Spiwoks-Becker et al. 2013). Similarly, in IHCs, a diverse spectrum of ribbons has also been observed (Bodian 1978; Sobkowicz et al. 1982; MerchanPerez and Liberman 1996; Wong et al. 2014). The specific ultrastructural properties seem to depend on several factors: (1) the maturation/age (see section above), (2) position within the inner hair cell and maybe also (3) dynamic adaptation to activity. A pioneering study in cats was one of the first to identify the correlation between structural heterogeneity of ribbon synapses and functional characteristics of auditory nerve fibers (Merchan-Perez and Liberman 1996). Surprisingly, large AZs with big and/or several ribbons, supposedly reflecting large presynaptic strength, seem to drive SGNs with low spontaneous rate and high thresholds (see also scheme in Fig. 2a). Whereas this conundrum remains unsolved, the mechanisms of functional presynaptic heterogeneity are now beginning to be understood. Evidence for such heterogeneity within individual IHCs was obtained using confocal imaging of presynaptic $\mathrm{Ca}^{2+}$ influx (Frank et al. 2009; see also Fig. 2b, b'). This study showed that presynaptic $\mathrm{Ca}^{2+}$ signals varied substantially in amplitude and voltagedependence among the AZs within individual IHCs. The amplitude of the $\mathrm{Ca}^{2+}$ signal scaled with ribbon size as approximated by simultaneous imaging of a fluorescently tagged RIBEYE-binding peptide (Frank et al. 2009) and seemed to be greater at the neural side of the IHCs (Meyer et al. 2009). Linking such estimates to the functional and morphological properties of the postsynaptic neurons will be an important task for future studies. So far, correlative arguments based on coincidental changes in maximal strength of presynaptic $\mathrm{Ca}^{2+}$ influx and postsynaptic spiking during development and upon genetic disruption as well as modeling have been brought forward to argue that strong synapses drive SGNs that have high spontaneous rates and low thresholds (Wong et al. 2013). Interestingly, an inverse correlation of pre- and postsynaptic parameters of synaptic strength has recently been reported for mouse IHCs: Liberman et al. (2011) suggested that synapses with many AMPA receptors exhibit small ribbons. The authors favored the interpretation that the SGNs inserting at the neural (modiolar) face of IHCs exhibit low spontaneous rates and high thresholds despite their corresponding large IHC AZs, because they have a smaller complement of AMPA receptors than those at the neural (pillar) side. This would agree with the conclusion of the classical study, which showed a neural-abneural gradient of AZ size using electron microscopy for cat IHCs whereby large AZs faced SGNs with low spontaneous rates and high thresholds (Merchan-Perez and Liberman 1996). In a laborious approach, the authors traced 11 functionally-characterized fibers to the IHCs using serial 3D reconstructions of ultrathin sections. In this way, it was possible to directly correlate morphological parameters such as ribbon length, fiber contact area, synaptic plaque area and synaptic vesicle numbers to the functional parameters determined prior to fiber labeling using single unit recordings. Recently, such a gradient was also suggested for mouse IHCs and reported to be influenced by the lateral olivocochlear innervation (Yin et al. 2014). The segregation of nerve fibers on neural and abneural sides was further observed in a study investigating the abundance of mitochondria in postsynaptic terminals. Here, postsynaptic boutons facing the abneural side seem to harbor more mitochondria (Francis et al. 2004). Monitoring EPSCs from single afferent boutons, which is a suitable method to address synaptic function on the level of individual release sites (Glowatzki and Fuchs 2002), further showed differences among synapses. In these experiments, 

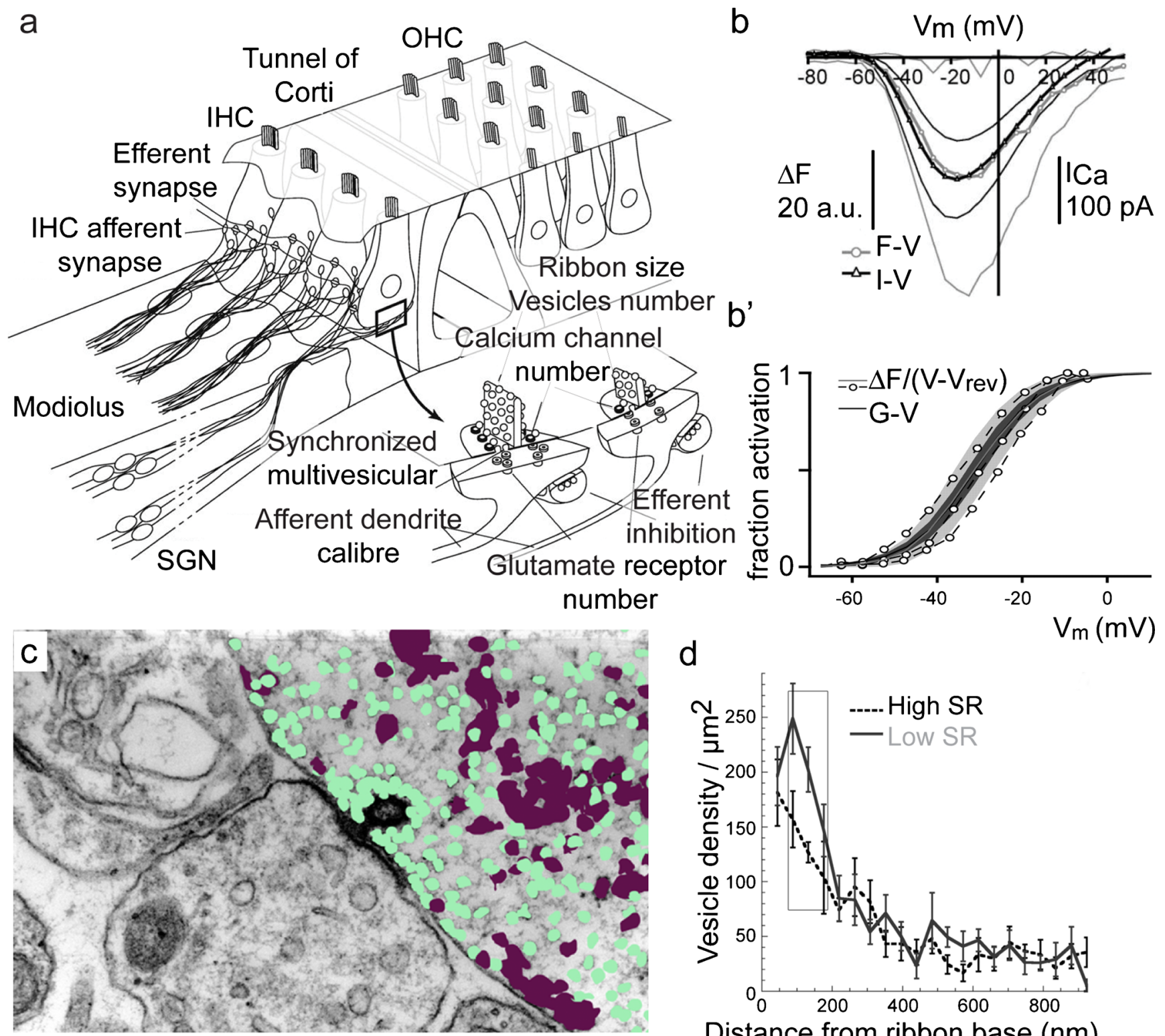

d
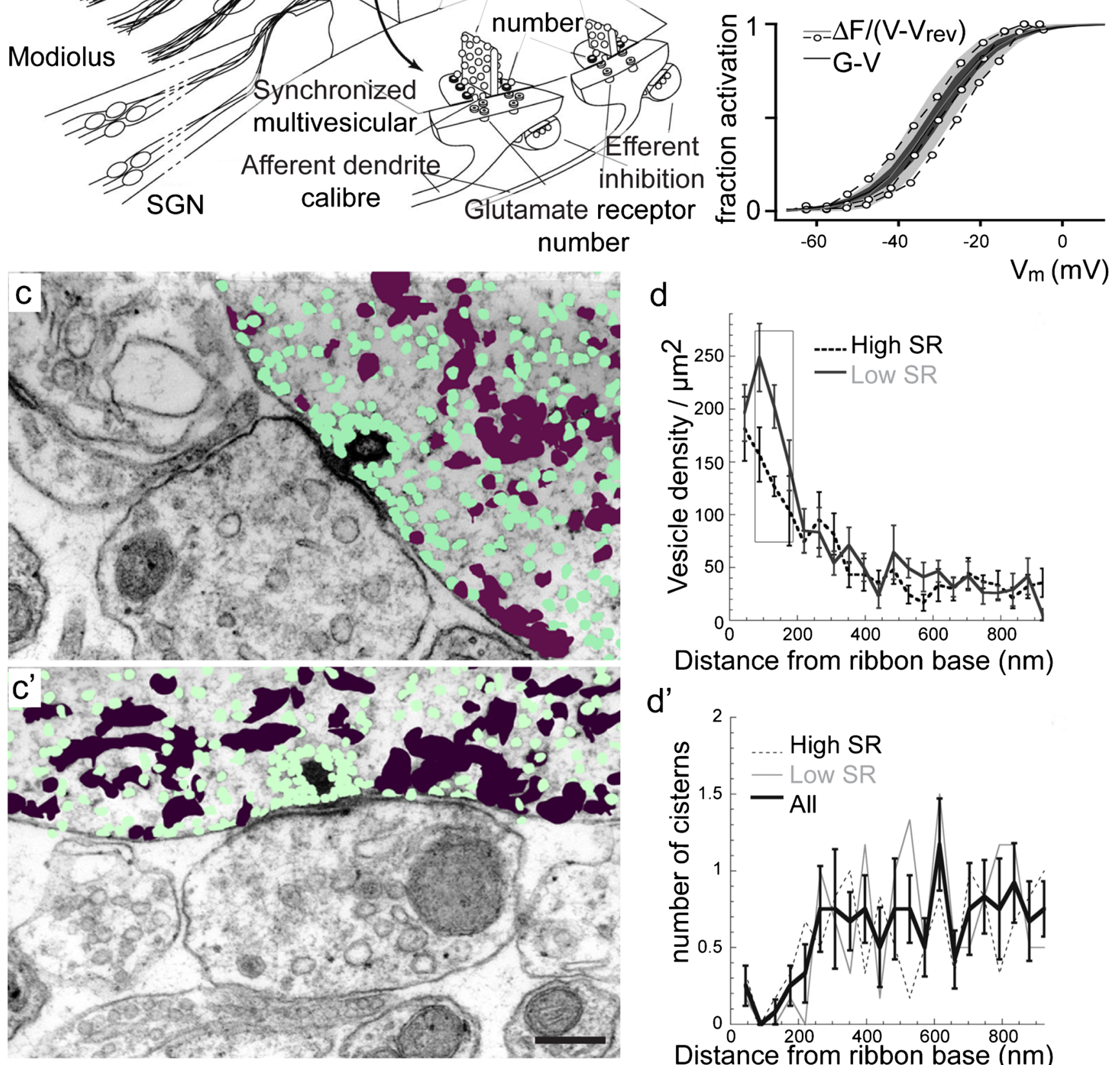

Distance from ribbon base $(\mathrm{nm})$ d'

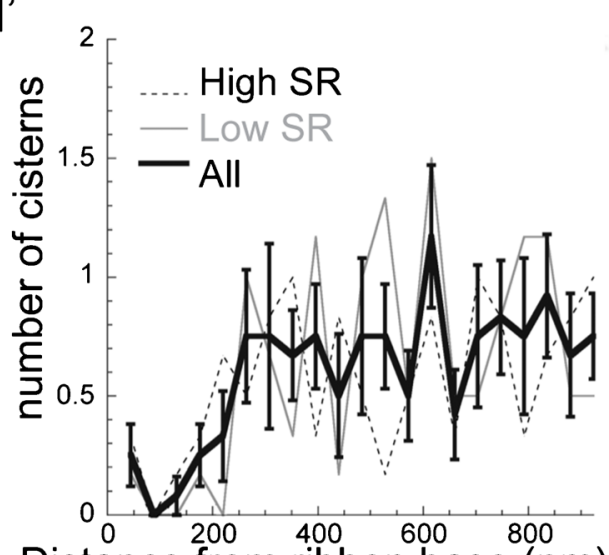

Distance from ribbon base $(\mathrm{nm})$ 
4 Fig. 2 Principle of functional heterogeneity in IHCs. a Schematic of an organ of Corti showing afferent and efferent innervations at IHCs. Modified from Meyer and Moser 2010, Curr Opin Otolaryngol Head Neck Surg, reprinted with permission from (C) 2010 Wolters Kluwer Health. $\mathbf{b}, \mathbf{b}$ ' Heterogeneous $\mathrm{Ca}^{2+}$ signaling in IHCs. b Mean and SD of $\Delta F$ (gray) as a function of depolarizing potential $\left(V_{\mathrm{m}}\right)$, obtained from spot-detection experiments at the center of the $\mathrm{Ca}^{2+}$ microdomain; $\Delta F$ was averaged over the last $15 \mathrm{~ms}$ of a 20 -ms stimulus. $\Delta F$ (mean gray) and $I_{\mathrm{Ca}}$ (mean black) show a similar voltage dependence (thin lines corresponding SDs). b' Heterogeneous voltage dependence and $\mathrm{Ca}^{2+}$ channel number of synaptic $\mathrm{Ca}^{2+}$ channel clusters in IHCs. Pronounced variability in the voltage dependence of activation, even within the same cell (dashed traces individual data curves from $3 \mathrm{Ca}^{2+}$ microdomains in an IHC). Modified from Frank et al. (2009), PNAS USA, with permission from (C) Frank et al. c, c' Colorized spatial distribution of vesicles and cisterns around the ribbon in low- and high-spontaneous rate (SR) fibers. Sections through a high-SR $(\mathbf{c})$ and a low-SR $\left(\mathbf{c}^{\prime}\right)$ synapse containing the synaptic ribbon are shown with cisternal (maroon) and vesicular (green) profiles. Scale bar (cm c') $200 \mathrm{~nm}$. d, d' Distribution of docked vesicles and cisterns. d Mean density $( \pm$ SE) of docked vesicles, i.e., within $20 \mathrm{~nm}$ of the presynaptic density along the presynaptic membrane. d' Mean number $( \pm$ SE) of cisterns within $20 \mathrm{~nm}$ of the presynaptic density versus distance along the presynaptic membrane is shown for all synapses. In addition, counts for low- and high-SR synapses are plotted separately. Rectangle the area of significant differences between low- and high-SR synapses. $S E$ standard error; $S R$ spontaneous rate. (c, c', d, d' modified from Kantardzhieva et al. 2013, J Comp Neurol, reprinted with permission from (C) 2013 Wiley Periodicals)

varying fractions of multiphasic EPSCs were observed and proposed to underlie the diverse firing properties of SGNs (Grant et al. 2010).

Further insights into the morphological heterogeneity require modern 3D reconstructions of larger volumes such as serial block face scanning electron microscopy (Denk and Horstmann 2004) or focused ion beam scanning electron microscopy (see, e.g., Knott et al. 2008; Kreshuk et al. 2011). Using these methods, a detailed 3D view of single IHCs including afferent and efferent innervations would be possible, finally allowing correlation of parameters, such as presynaptic ribbon size and postsynaptic bouton diameter, as a function of position on the IHC for a large number of synapses, together with the functional assessment of pre- and postsynaptic properties in cochlear explants by electrophysiology (Goutman and Glowatzki 2007) and/or imaging of $\mathrm{IHC} \mathrm{Ca}^{2+}$ and exocytosis (e.g., Frank et al. 2009; Neef et al. 2014) and postsynaptic activity (Boyer et al. 2004).

Synaptic vesicle recycling in inner hair cells

Tight coupling between exo- and endocytosis is a prerequisite for maintaining the enormous vesicle turnover rates at ribbon synapses. The underlying mechanisms of endocytosis in IHCs are just starting to become uncovered. Clathrincoated structures but also large cisterns without clathrincoats, are observed close to synaptic ribbons (Siegel and Brownell 1986; Sendin et al. 2007; Frank et al. 2010;
Kantardzhieva et al. 2013; Neef et al. 2014; Revelo et al. 2014). Kantardzhieva et al. (2013) set out to determine whether such cisterns participate in vesicle reformation and what differences can be observed in correlation to the functional properties of high and low spontaneous rate fibers (Fig. 2c, c', d, d'). An extensive quantitative analysis of ribbons, vesicles and cisterns from serial sections of cat IHC ribbon synapses suggested a 'sphere of influence' of $350 \mathrm{~nm}$ around the ribbon (Kantardzhieva et al. 2013). Here, fewer cisterns and more synaptic vesicles are found, which indeed points towards a contribution of cisterns to locally restricted vesicle formation. Other studies used membrane capacitance measurements to provide an initial functional assessment of endocytic membrane retrieval at IHC AZs (Moser and Beutner 2000; Beutner and Moser 2001; Neef et al. 2014). Moreover, $\mathrm{pH}$-sensitive GFP (pHluorin; Miesenböck et al. 1998) targeted to the intraluminal face of vesicle membranes by attachment to vesicular glutamate transporters (Zhu et al. 2009) has become an important tool in studying exo- and endocytosis, not only from neurons but also IHCs (Neef et al. 2014; Revelo et al. 2014). Additionally, a novel membrane tracer specifically tailored to use in the organ of Corti has been devised and applied to investigate endocytosis (Revelo et al. 2014), as the commonly used styryl dye FM1-43 penetrates stereociliar mechanotransduction channels and hence is of limited use to study endocytosis, in IHCs (Gale et al. 2001; Kamin et al. 2014; Revelo et al. 2014). To date, expression analysis and immunohistochemistry have revealed the presence of several important molecular players of endocytosis such as dynamins, amphiphysin, clathrin (Neef et al. 2014) and adaptor protein 2 (AP-2) (Duncker et al. 2013) in IHCs. A very recent DNA microarray study investigating IHC and $\mathrm{OHC}$ transcriptomes might even give more insight into proteins involved in vesicle recycling (Liu et al. 2014).

Currently, in IHCs, three distinct mechanisms are considered to mediate endocytosis: slow CME, fast bulk endocytosis and potentially kiss-and-run or 'ultrafast' endocytosis (Neef et al. 2014). CME is the main pathway of membrane retrieval for mild stimulation and proceeds at a constant rate; it represents the linear component of endocytosis following exocytosis of the RRP (Fig. 3a). This mechanism is not only inhibited by the clathrin-inhibitor pitstop-2 but also by disruption of dynamin 1 via pharmacological and genetic means (Neef et al. 2014). None of these manipulations seem to affect exocytosis. In contrast, a different study reported inhibition of sustained exocytosis by the presumptive dynamin inhibitor dynasore but did not investigate endocytic membrane retrieval (Duncker et al. 2013). Finally, when exocytosis exceeds three to four RRP equivalents, IHCs additionally recruit a faster mode of membrane retrieval, which proceeds with an exponential time course within a few seconds. It has been proposed to represent bulk endocytosis (Neef et al. 2014; Fig. 3a') and, 
indeed, there is plenty of evidence for the invagination and fission of large stretches of plasma membrane in the vicinity of hair cell AZs (Lenzi et al. 2002; Frank et al. 2010; Pangršič et al. 2010; Kamin et al. 2014; Neef et al. 2014; Revelo et al. 2014). Both mechanisms seem to engage in different phases of release: CME supports vesicle cycling during mild stimulation but bulk endocytosis finally occurs after prolonged stimulation, providing a mechanism that assures the balance between exo- and endocytosis in IHCs and thus, assures high release rates (Neef et al. 2014).

But where does the retrieval of synaptic vesicle membrane take place and where and how are synaptic vesicles regenerated following membrane retrieval in hair cells? Does synaptic endocytosis comply with the apicobasal compartmentalization of the hair cell? At photoreceptor ribbons, a periactive zone, marked by the presence of endocytic proteins, was identified directly adjacent to the AZ area (in a range of $120-250 \mathrm{~nm}$ from the ribbon) using high-resolution and electron microscopy (Wahl et al. 2013). But does this also apply to IHC ribbons? At the resolution of confocal microscopy, a similar perisynaptic accumulation of endocytic proteins has, so far, not been found (Neef et al. 2014); however, future studies using nanoscopy will hopefully clarify this issue. Clearly, electron micrographs indicate that both bulk and CME endocytosis take place near the AZ (Siegel and Brownell 1986; Lenzi et al. 2002; Frank et al. 2010; Kamin et al. 2014; Neef et al. 2014). A radically different model of IHC endocytosis has been sketched based on life imaging of FM1-43 uptake into IHCs, whereby exocytosed membrane was postulated to move towards the IHC apex for endocytosis and recycling via the Golgi apparatus (Griesinger et al. 2002, 2005). Recent elaborative studies using various styryl dyes and more suitable fluorescent membrane markers lead us to reconsider this hypothesis. First, it was corroborated that many styryl dyes including FM1-43 permeate into the cytosol of IHCs via the mechanotransducer channels (Kamin et al. 2014; Revelo et al. 2014). Therefore, on the ultrastructural level, the photo-oxidation technique revealed a fuzzy dark diaminobenzidin (DAB) smear inside the cytosol in addition to the precipitate in membrane-bound organelles likely resulting from internalized FM1-43. The stimulation-induced endocytic uptake of FM1-43 could still be followed by observing an electron-dense precipitate within vesicular structures, which allows the determination of the presence or absence as well as the localization of stained structures under resting (Fig. 3b), stimulated (Fig. 3b') and recovery (Fig. 3b", b"') conditions in serial 3D reconstructed IHCs (Kamin et al. 2014). At rest, endosome-like organelles were detected in the apex of the IHCs, whereas larger tubulo-cisternal organelles dominated at the nuclear region. At the basal region, only a few labeled structures were present. Stimulation massively increased the amount of basolateral membrane trafficking, reflected by the appearance of labeled small vesicles and endosome-like vacuoles; however, no changes in the apical and nuclear regions could be observed (Kamin et al. 2014; Fig. 3b'). Strikingly, the basolateral cisterns were replaced in the basal region by small, synaptic-like vesicles during a few minutes of recovery from stimulation, suggesting a highly efficient mechanism of vesicle regeneration from cisternal membranes internalized by bulk endocytosis. The combination of FM1-43 uptake and photo-oxidation therefore suggests that synaptic vesicle recycling takes place at the basal part, close to ribbons at least during synaptic activity (Kamin et al. 2014).

Recently, a novel membrane tracer, named membranebinding fluorophore-cysteine-lysine-palmitoyl group (mCLING), which does not permeate the mechanotransducer channel, tightly binds biological membranes and can be fixed, has been developed (Revelo et al. 2014). In combination with super-resolution light microscopy (i.e., STED), the spatial organization and pathways of endocytosis in IHCs could be further investigated. In order to improve the spatial resolution

Fig. 3 Endocytosis in inner hair cells. a, a' Representative recordings in response to $20 \mathrm{~ms}$ (a) or $200 \mathrm{~ms}$ (a') depolarizations. After the $C_{\mathrm{m}}$ increase upon $20 \mathrm{~ms}$ depolarization, the slope-corrected $C_{\mathrm{m}}$ traces (middle) typically showed a linear decay (a). The 200-ms-long depolarization resulted in a combination of exponential and linear decay (a'). Modified from Neef et al. (2014) reprinted with permission from (C) 2014 Neef et al. b-b"' 3D reconstructions of resting (b), stimulated (b') and recovered IHCs (b", b"'). Endocytotic organelles are shown in purple. Note the presence of tubular organelles both before and after stimulation. Most organelles, including the tubular ones, are replaced by small vesicles during the recovery periods. Insets magnified regions from the four different cell regions (cuticular plate, top, nuclear and basal regions). Note the increased number of endosome-like organelles at the base of the cell after stimulation and during recovery. Modified from Kamin et al. (2014), reprinted with permission (C) 2014 Kamin et al. c mCLING-labeled organs of Corti were immunostained for Vglut3 and otoferlin (first row), for Vglut3 and syntaxin 6 (Sx 6, second row), for otoferlin and syntaxin 16 (Sx 16, third row) and finally for syntaxin 6 and syntaxin 16 (fourth row). The samples were cut into 20-nm sections and were imaged using an epifluorescence microscope. Dashed white lines the plasma membrane of the IHCs. White arrowheads organelles where the signals for mCLING and the two immunostained proteins colocalized. Scale bar $2 \mu \mathrm{m}$. d Graphic representation of Pearson's correlation coefficients: otoferlin and syntaxin 6 (or syntaxin 16) correlate in the mCLING-labeled organelles at the top and nuclear levels. Vglut3 correlates best with otoferlin at the basal level. At least 100 organelles were analyzed for each condition. Error bars SEMs. e Model of membrane recycling in IHCs. Organelles with a different molecular composition recycle membrane in different regions, taking up mCLING. Apical endocytosis takes up the membrane into round organelles, a sizeable proportion of which is similar to late endosomes (light blue). Endocytosis in the top and nuclear regions reaches tubular organelles containing otoferlin and two endosome markers, syntaxin 16 and syntaxin 6 . This suggests that these organelles participate in constitutive pathways, probably by maintaining membrane traffic between the plasma membrane and the trans-Golgi. At the base of the cell, stimulation induces the formation of membrane infoldings and cisterns that are characterized by the presence of Vglut3, Rab3 and also otoferlin. (c-e modified from Revelo et al. 2014, reprinted with permission from (C) 2014 Revelo et al.) 


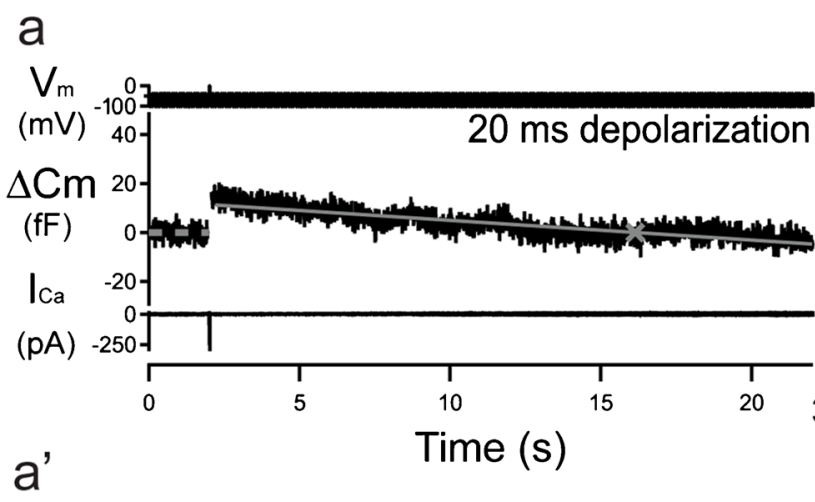

b Resting

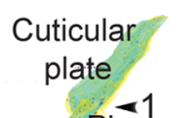

Plasma

membrane

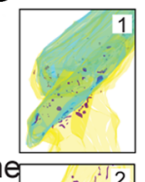

b' Stimulated
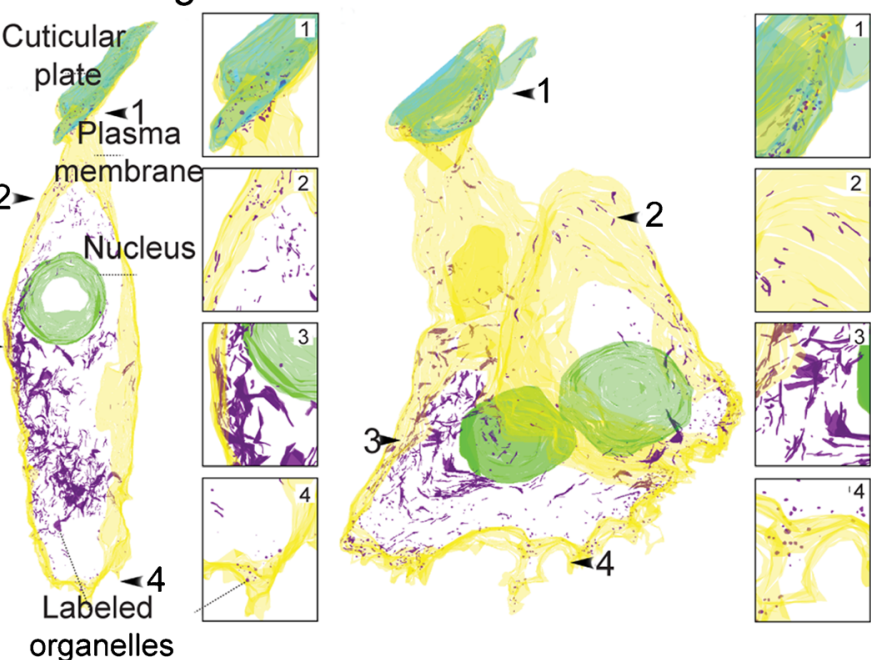

$\Delta \mathrm{fF})$

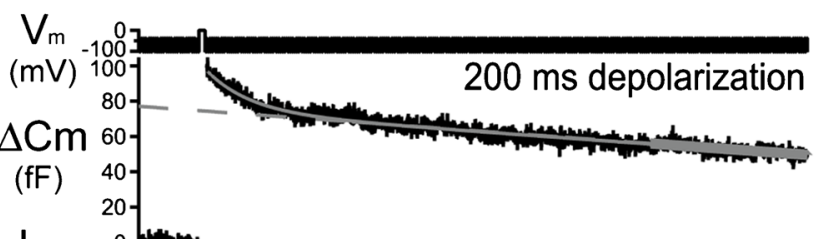

organelles

ICa $0-1+m$

b" Recovery 5'
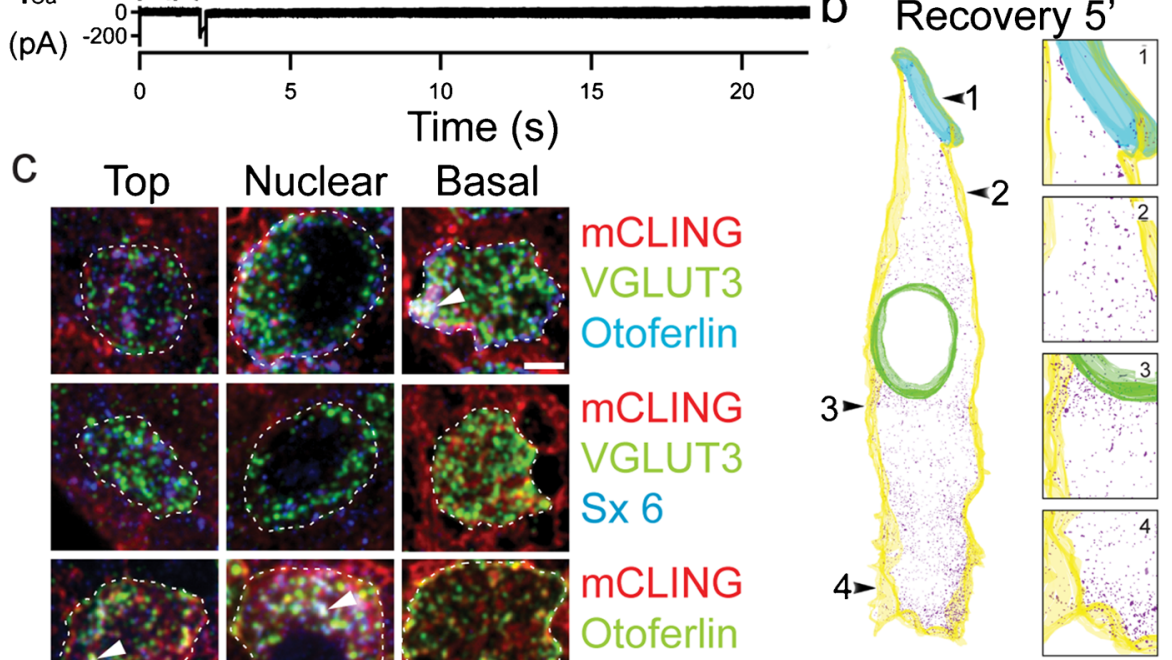

b"' Recovery 30'

Time (s)

C
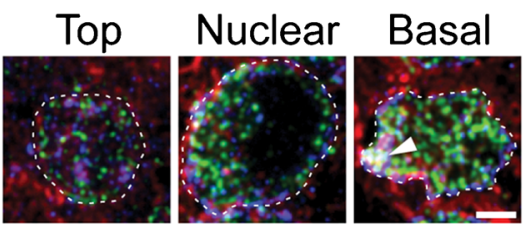

mCLING

VGLUT3
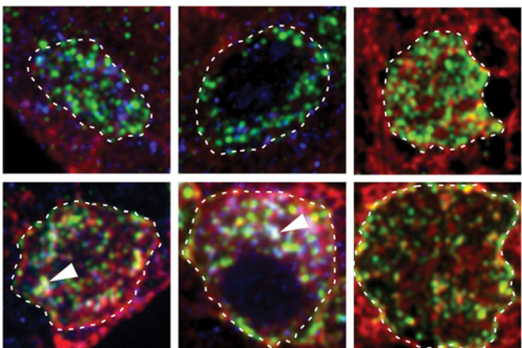

Otoferlin

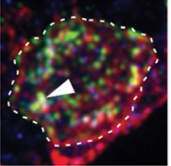

mCLING

VGLUT3

Sx 6
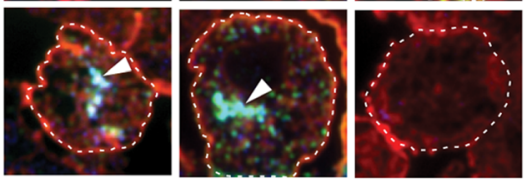

mCLING

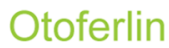

Sx 16

d

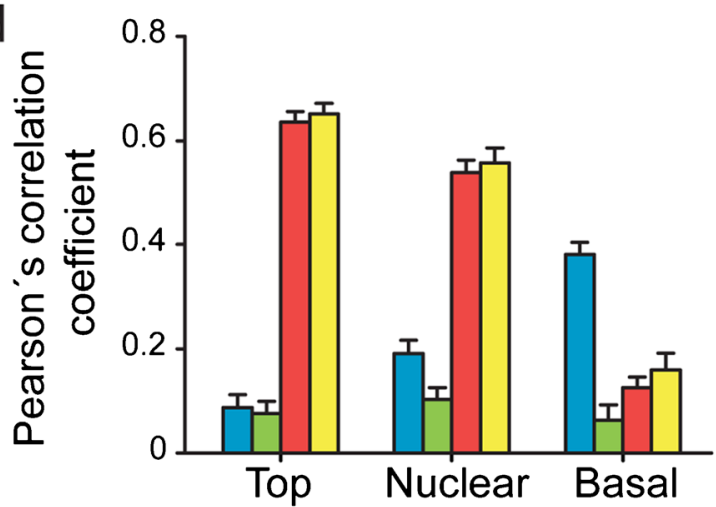

VGLUT3 - Otoferlin

$\square$ Otoferlin - Sx 16

mCLING

Sx 6

Sx 16

VGLUT3 - Sx $6 \square$ Sx 6 - Sx 16

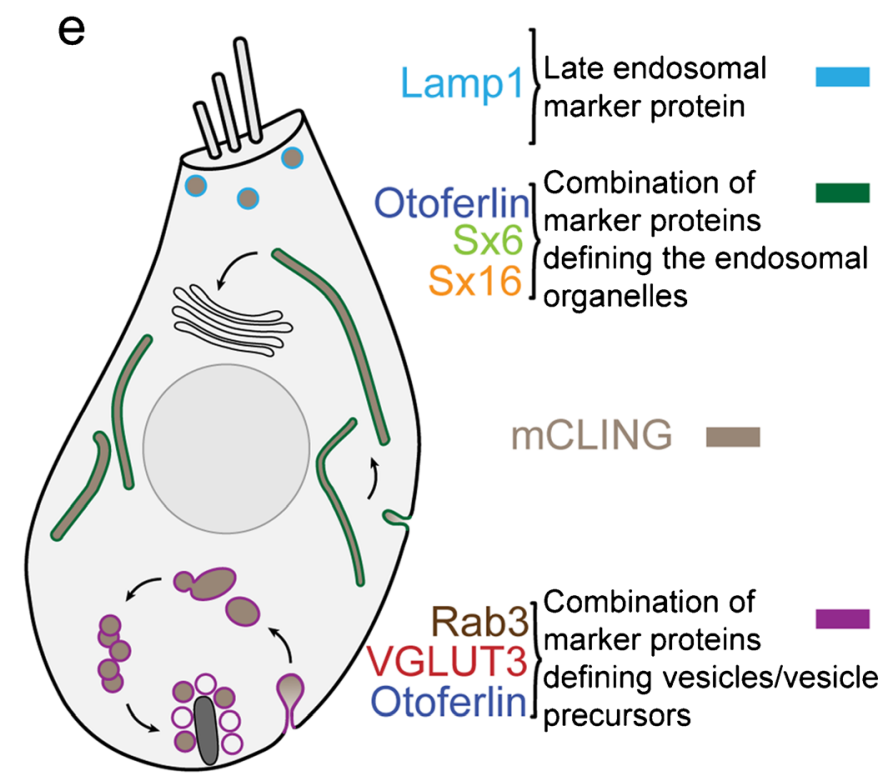


of STED microscopy in the axial direction, thin sections of IHCs were imaged after embedding the organs of Corti in melamine, which maintains the fluorescence (Revelo et al. 2014). The apical, nuclear and basal regions under conditions of rest, stimulation and recovery from stimulation, were investigated and the uptake of mCLING monitored. In order to reveal the molecular identity of mCLING-labeled structures and thereby identify the respective endocytic pathways, samples were co-stained with different protein markers for the endoplasmic reticulum (ER) and Golgi as well as synaptic vesicle endo- and exocytosis. In these experiments, a strong correlation for basolateral mCLING localization with Vglut3, rab3 and otoferlin immunofluorescence was found. Otoferlin as well as syntaxin 16, a late endosomal marker, colocalized with apical and nuclear mCLING (Fig. 3c-e). Moreover, the lysosomal-associated membrane protein 1 (LAMP1) colocalized with mCLING in the apical region of the IHC. Stimulation led to a selective uptake of mCLING at the base of the IHC, corroborating the notion of local recycling of synaptic vesicles that was postulated based on electron microscopy and photo-oxidation (Kamin et al. 2014; Revelo et al. 2014). The local recycling hypothesis was further supported by the finding that exogenous Vglut1-pHluorin fluorescence not only transiently appeared at ribbon-type AZs but remained there for tens of seconds after stimulation (Neef et al. 2014; Revelo et al. 2014).

Finally, the mCLING experiments revealed large membranous organelles near synapses, which were replaced by small organelles a few minutes after stimulation, thereby providing direct evidence of bulk endocytosis and vesicle regeneration from the internalized plasma membrane. The association of otoferlin with all three putative membrane recycling pathways suggests a more general role of this protein in endocytosis. Otoferlin has recently been assigned a role in vesicle endocytosis due to its interaction with AP-2. Using a high-resolution liquid chromatography coupled with a mass spectrometry approach, multiple subunits of AP-2 were identified as interaction partners of otoferlin in the mammalian cochlea and the proposed interactions were biochemically confirmed by coimmunoprecipitation (Duncker et al. 2013). AP-2 plays a role in clathrin-mediated endocytosis via binding to clathrincoated vesicles budding from the plasma membrane (Keyel et al. 2008; Boucrot et al. 2010) and has been shown to be expressed in IHCs (Duncker et al. 2013). Future work is required to clarify the role of AP-2 in hair cell endocytosis and the relevance of its interaction with otoferlin.

\section{Outlook}

Recently, major progress has been made towards dissecting the molecular anatomy and physiology of hair cell ribbon synapses. This includes powerful single synapse techniques such as (1) patch-clamp of postsynaptic afferent terminals of
SGNs, (2) high resolution -functional imaging of presynaptic IHC $\mathrm{Ca}^{2+}$ dynamics and membrane turnover, as well as (3) super-resolution light microscopy and electron tomography following high-pressure freezing. However, in order to investigate the release mechanisms of IHCs and firmly correlate structure and function, the development of new functional and morphological approaches is required. Functional and morphological analysis of single synapses will be necessary and some questions require reading out both pre- and postsynaptic properties at the same time. The commonly used $\mathrm{K}^{+}$ stimulation of cochlear tissue likely mimics strong physiological steady-state stimulation. But this stimulation does not provide the temporal resolution to allow the observation of the release kinetics at IHC ribbon synapses. Especially, knowledge about short-term plastic changes is lacking, since it is not possible to apply very short stimuli (i.e., millisecond range) and investigate the cells during and at defined times after stimulation. Therefore, approaches are needed that meet two requirements: (1) a precise stimulation protocol combined with (2) rapid immobilization of the sample, e.g., by using high-pressure freezing. One emerging tool that promises to fulfill these requirements is the combination of optogenetic stimulation with high-pressure freezing. This could involve the expression of a light-sensitive ion channel such as channelrhodopsin-2 (ChR-2) from the green algae Chlamydomonas reinhardii (Nagel et al. 2003) in hair cells and stimulation would ideally be performed within a chamber that should be mounted in a freezing machine in order to minimize the time delay before freezing. Such optogenetic investigations of synapses combined with electron microscopy have been emerging. Recently, synaptic recovery of motoneurons from C. elegans was analyzed using optogenetic stimulation in combination with high-pressure freezing (Kittelmann et al. 2013). Moreover, after a single light stimulus, docked vesicles fused along a broad $\mathrm{AZ}$ on $C$. elegans motoneurons expressing ChR-2. These vesicles were replenished with a time constant of about 2 s. Further, endocytosis occurred within $50 \mathrm{~ms}$ adjacent to the dense projection and after $1 \mathrm{~s}$ adjacent to adherens junctions (Watanabe et al. 2013a). Moreover, a study on optically stimulated cultured hippocampal neurons revealed an ultrafast endocytosis mechanism at central synapses (Watanabe et al. 2013b). These initial experiments indicate that optogenetics, in combination with high-pressure freezing ('flash and freeze'; Watanabe et al. 2013b) and subsequent electron tomography, might provide sufficient resolution to study the ultrastructure of spatiotemporally defined functional states and thus provide a completely new view on the release mechanism of IHC ribbon synapses.

Acknowledgments We thank Dr. Christian Vogl, Dr. Tina Pangršič and Dr. Susanne Vetterkind for carefully reading and giving comments on the 
manuscript. This work was supported by the German Research Foundation through the Collaborative Research Center 889 to T.M. (projects A2 and A5) and C.W. (project A7) and the Göttingen Center for Nanoscopy and Molecular Physiology of the Brain (to T.M.) and the German Federal Ministry of Education and Research (through Bernstein Center grant 01GQ0433 to T.M.).

Open Access This article is distributed under the terms of the Creative Commons Attribution License which permits any use, distribution, and reproduction in any medium, provided the original author(s) and the source are credited.

\section{References}

Altrock WD et al (2003) Functional inactivation of a fraction of excitatory synapses in mice deficient for the active zone protein bassoon. Neuron 37:787-800

Antonellis PJ, Pollock LM, Chou S-W, Hassan A, Geng R, Chen X, Fuchs E, Alagramam KN, Auer M, McDermott BM (2014) ACF7 is a hair-bundle antecedent, positioned to integrate cuticular plate actin and somatic tubulin. J Neurosci 34:305-312

Betz A, Ashery U, Rickmann M, Augustin I, Neher E, Südhof TC, Rettig J, Brose N (1998) Munc13-1 is a presynaptic phorbol ester receptor that enhances neurotransmitter release. Neuron 21:123-136

Betz A, Thakur P, Junge HJ, Ashery U, Rhee J-S, Scheuss V, Rosenmund C, Rettig J, Brose N (2001) Functional interaction of the active zone proteins Munc13-1 and RIM1 in synaptic vesicle priming. Neuron 30:183-196

Beurg M, Safieddine S, Roux I, Bouleau Y, Petit C, Dulon D (2008) Calcium- and otoferlin-dependent exocytosis by immature outer hair cells. J Neurosci 28:1798-1803

Beurg M, Michalski N, Safieddine S, Bouleau Y, Schneggenburger R, Chapman ER, Petit C, Dulon D (2010) Control of exocytosis by synaptotagmins and otoferlin in auditory hair cells. J Neurosci 30: 13281-13290

Beutner D, Moser T (2001) The presynaptic function of mouse cochlear inner hair cells during development of hearing. J Neurosci 21:4593

Bodian D (1978) Synapses involving auditory nerve fibers in primate cochlea. Proc Natl Acad Sci U S A 75:4582-4586

Boucrot E, Saffarian S, Zhang R, Kirchhausen T (2010) Roles of AP-2 in clathrin-mediated endocytosis. PLoS ONE 5:e10597

Boyer S, Ruel J, Puel J-L, Chabbert C (2004) A procedure to label inner ear afferent nerve endings for calcium imaging. Brain Res Brain Res Protocol 13:91-98

Brandstätter JH, Wässle H, Betz H, Morgans CW (1996) The plasma membrane protein SNAP-25, but not syntaxin, is present at photoreceptor and bipolar cell synapses in the rat retina. Eur J Neurosci 8: 823-828

Brandt A, Striessnig J, Moser T (2003) CaV1. 3 channels are essential for development and presynaptic activity of cochlear inner hair cells. J Neurosci 23:10832-10840

Bunt AH (1971) Enzymatic digestion of synaptic ribbons in amphibian retinal photoreceptors. Brain Res 25:571-577

Buran BN, Strenzke N, Neef A, Gundelfinger ED, Moser T, Liberman MC (2010) Onset coding is degraded in auditory nerve fibers from mutant mice lacking synaptic ribbons. J Neurosci 30:7587-7597

Chapochnikov NM, Takago H, Huang C-H, Pangršič T, Khimich D, Neef J, Auge E, Göttfert F, Hell SW, Wichmann C, Wolf F, Moser T (2014) Uniquantal release through a dynamic fusion pore is a candidate mechanism of hair cell exocytosis. Neuron 17:1389-1403

Clause A, Kim G, Sonntag M, Weisz CJC, Vetter DE, Rübsamen R, Kandler K (2014) The precise temporal pattern of prehearing spontaneous activity is necessary for tonotopic map refinement. Neuron 82:822-835

Cooper B, Hemmerlein M, Ammermüller J, Imig C, Reim K, Lipstein N, Kalla S, Kawabe H, Brose N, Brandstätter JH, Varoqueaux F (2012) Munc13-independent vesicle priming at mouse photoreceptor ribbon synapses. J Neurosci 32:8040-8052

Corey DP, Hudspeth AJ (1979) Ionic basis of the receptor potential in a vertebrate hair cell. Nature 281:675-677

De Robertis ED, Bennett HS (1955) Some features of the submicroscopic morphology of synapses in frog and earthworm. J Biophys Biochem Cytol 1:47-58

De Robertis E, Franchi CM (1956) Electron microscope observations on synaptic vesicles in synapses of the retinal rods and cones. J Biophys Biochem Cytol 2:307-318

DeFelipe J, Hendry SH, Jones EG (1986) A correlative electron microscopic study of basket cells and large GABAergic neurons in the monkey sensory-motor cortex. Neuroscience 17: 991-1009

Deguchi-Tawarada M, Inoue E, Takao-Rikitsu E, Inoue M, Kitajima I, Ohtsuka T, Takai Y (2006) Active zone protein CAST is a component of conventional and ribbon synapses in mouse retina. J Comp Neurol 495:480-496

Denk W, Horstmann H (2004) Serial block-face scanning electron microscopy to reconstruct three-dimensional tissue nanostructure. PLoS Biol 2:e329

Dick O, Hack I, Altrock WD, Garner CC, Gundelfinger ED, Brandstätter JH (2001) Localization of the presynaptic cytomatrix protein Piccolo at ribbon and conventional synapses in the rat retina: comparison with bassoon. J Comp Neurol 439:224-234

Dick O, tom Dieck S, Altrock WD, Ammermüller J, Weiler R, Garner CC, Gundelfinger ED, Brandstätter JH (2003) The presynaptic active zone protein bassoon is essential for photoreceptor ribbon synapse formation in the retina. Neuron 37:775-786

Dou H, Vazquez AE, Namkung Y, Chu H, Cardell EL, Nie L, Parson S, Shin H-S, Yamoah EN (2004) Null mutation of alpha1D $\mathrm{Ca}^{2+}$ channel gene results in deafness but no vestibular defect in mice. J Assoc Res Otolaryngol 5:215-226

Dresbach T, Qualmann B, Kessels MM, Garner CC, Gundelfinger ED (2001) The presynaptic cytomatrix of brain synapses. Cell Mol Life Sci 58:94-116

Dulon D, Safieddine S, Jones SM, Petit C (2009) Otoferlin is critical for a highly sensitive and linear calcium-dependent exocytosis at vestibular hair cell ribbon synapses. J Neurosci 29:10474-10487

Duncker SV, Franz C, Kuhn S, Schulte U, Campanelli D, Brandt N, Hirt B, Fakler B, Blin N, Ruth P, Engel J, Marcotti W, Zimmermann U, Knipper M (2013) Otoferlin couples to clathrin-mediated endocytosis in mature cochlear inner hair cells. J Neurosci 33:9508-9519

Echteler SM (1992) Developmental segregation in the afferent projections to mammalian auditory hair cells. Proc Natl Acad Sci U S A 89:6324-6327

Edmonds BW (2004) Evidence that fast exocytosis can be predominantly mediated by vesicles not docked at active zones in frog saccular hair cells. J Physiol 560:439-450

Ezan J, Montcouquiol M (2013) Revisiting planar cell polarity in the inner ear. Semin Cell Dev Biol 24:499-506

Fenster SD, Chung WJ, Zhai R, Cases-Langhoff C, Voss B, Garner AM, Kaempf U, Kindler S, Gundelfinger ED, Garner CC (2000) Piccolo, a presynaptic zinc finger protein structurally related to bassoon. Neuron 25:203-214

Fenster SD, Kessels MM, Qualmann B, Chung WJ, Nash J, Gundelfinger ED, Garner CC (2003) Interactions between piccolo and the actin/ dynamin-binding protein Abp1 link vesicle endocytosis to presynaptic active zones. J Biol Chem 278:20268-20277

Fernández-Busnadiego R, Zuber B, Maurer UE, Cyrklaff M, Baumeister W, Lucic V (2010) Quantitative analysis of the native presynaptic cytomatrix by cryoelectron tomography. J Cell Biol 188:145-156 
Fernández-Busnadiego R, Asano S, Oprisoreanu A-M, Sakata E, Doengi M, Kochovski Z, Zürner M, Stein V, Schoch S, Baumeister W, Lucić V (2013) Cryo-electron tomography reveals a critical role of RIM1 $\alpha$ in synaptic vesicle tethering. J Cell Biol 201:725-740

Francis HW, Rivas A, Lehar M, Ryugo DK (2004) Two types of afferent terminals innervate cochlear inner hair cells in C57BL/6J mice. Brain Res 1016:182-194

Francis HW, Rivas A, Lehar M, Saito Y, Mouton PR, Ryugo DK (2006) Efficient quantification of afferent cochlear ultrastructure using design-based stereology. J Neurosci Methods 150:150-158

Frank T, Khimich D, Neef A, Moser T (2009) Mechanisms contributing to synaptic $\mathrm{Ca}^{2+}$ signals and their heterogeneity in hair cells. Proc Natl Acad Sci U S A 106:4483

Frank T, Rutherford MA, Strenzke N, Neef A, Pangršič T, Khimich D, Fejtova A, Gundelfinger ED, Liberman MC, Harke B, Bryan KE, Lee A, Egner A, Riedel D, Moser T (2010) Bassoon and the synaptic ribbon organize $\mathrm{Ca}^{2}+$ channels and vesicles to add release sites and promote refilling. Neuron 68:724-738

Fuchs PA (2005) Time and intensity coding at the hair cell's ribbon synapse. J Physiol 566:7-12

Fuchs PA, Evans MG, Murrow BW (1990) Calcium currents in hair cells isolated from the cochlea of the chick. J Physiol 429:553-568

Furness DN, Hackney CM, Steyger PS (1990) Organization of microtubules in cochlear hair cells. J Electron Microsc Tech 15:261-279

Furukawa T, Hayashida Y, Matsuura S (1978) Quantal analysis of the size of excitatory post-synaptic potentials at synapses between hair cells and afferent nerve fibres in goldfish. J Physiol 276:211

Gale JE, Marcotti W, Kennedy HJ, Kros CJ, Richardson GP (2001) FM143 dye behaves as a permeant blocker of the hair-cell mechanotransducer channel. J Neurosci 21:7013-7025

Géléoc GSG, Holt JR (2003) Developmental acquisition of sensory transduction in hair cells of the mouse inner ear. Nat Neurosci 6:10191020

Ginzberg RD, Morest DK (1984) Fine structure of cochlear innervation in the cat. Hear Res 14:109-127

Glowatzki E, Fuchs PA (2000) Cholinergic synaptic inhibition of inner hair cells in the neonatal mammalian cochlea. Science 288:2366

Glowatzki E, Fuchs PA (2002) Transmitter release at the hair cell ribbon synapse. Nat Neurosci 5:147-154

Goutman JD (2012) Transmitter release from cochlear hair cells is phase locked to cyclic stimuli of different intensities and frequencies. J Neurosci 32:17025-17036

Goutman JD, Glowatzki E (2007) Time course and calcium dependence of transmitter release at a single ribbon synapse. Proc Natl Acad Sci U S A 104:16341-16346

Goutman JD, Fuchs PA, Glowatzki E (2005) Facilitating efferent inhibition of inner hair cells in the cochlea of the neonatal rat. J Physiol 566:49-59

Grant L, Yi E, Glowatzki E (2010) Two modes of release shape the postsynaptic response at the inner hair cell ribbon synapse. $\mathrm{J}$ Neurosci 30:4210-4220

Gray EG, Pease HL (1971) On understanding the organisation of the retinal receptor synapses. Brain Res 35:1-15

Graydon CW, Cho S, Li G-L, Kachar B, von Gersdorff H (2011) Sharp $\mathrm{Ca}^{2+}$ nanodomains beneath the ribbon promote highly synchronous multivesicular release at hair cell synapses. J Neurosci 31:1663716650

Graydon CW, Zhang J, Oesch NW, Sousa AA, Leapman RD, Diamond JS (2014) Passive diffusion as a mechanism underlying ribbon synapse vesicle release and resupply. J Neurosci 34:8948-8962

Griesinger CB, Richards CD, Ashmore JF (2002) FM1-43 reveals membrane recycling in adult inner hair cells of the mammalian cochlea. $\mathrm{J}$ Neurosci 22:3939

Griesinger CB, Richards CD, Ashmore JF (2005) Fast vesicle replenishment allows indefatigable signalling at the first auditory synapse. Nature 435:212-215
Hallermann S, Silver RA (2013) Sustaining rapid vesicular release at active zones: potential roles for vesicle tethering. Trends Neurosci 36:185-194

Hallermann S, Kittel RJ, Wichmann C, Weyhersmüller A, Fouquet W, Mertel S, Owald D, Eimer S, Depner H, Schwärzel M, Sigrist SJ, Heckmann M (2010) Naked dense bodies provoke depression. J Neurosci 30:14340-14345

Harlow ML, Ress D, Stoschek A, Marshall RM, McMahan UJ (2001) The architecture of active zone material at the frog's neuromuscular junction. Nature 409:479-484

Heidelberger R, Heinemann C, Neher E, Matthews G (1994) Calcium dependence of the rate of exocytosis in a synaptic terminal. Nature 371:513-515

Heidrych P, Zimmermann U, Kuhn S, Franz C, Engel J, Duncker SV, Hirt B, Pusch CM, Ruth P, Pfister M, Marcotti W, Blin N, Knipper M (2009) Otoferlin interacts with myosin VI: implications for maintenance of the basolateral synaptic structure of the inner hair cell. Hum Mol Genet 18:2779-2790

Hell SW (2007) Far-field optical nanoscopy. Science 316:1153-1158

Huang L-C, Thorne PR, Housley GD, Montgomery JM (2007) Spatiotemporal definition of neurite outgrowth, refinement and retraction in the developing mouse cochlea. Development 134:29252933

Huang L-C, Barclay M, Lee K, Peter S, Housley GD, Thorne PR, Montgomery JM (2012) Synaptic profiles during neurite extension, refinement and retraction in the developing cochlea. Neural Dev 7: $1-17$

Issa NP, Hudspeth AJ (1996) The entry and clearance of Ca2+ at individual presynaptic active zones of hair cells from the bullfrog's sacculus. Proc Natl Acad Sci U S A 93:9527

Jahn R, Fasshauer D (2012) Molecular machines governing exocytosis of synaptic vesicles. Nature 490:201-207

Jing Z, Rutherford MA, Takago H, Frank T, Fejtova A, Khimich D, Moser T, Strenzke N (2013) Disruption of the presynaptic cytomatrix protein bassoon degrades ribbon anchorage, multiquantal release, and sound encoding at the hair cell afferent synapse. J Neurosci 33:4456-4467

Johnson CP, Chapman ER (2010) Otoferlin is a calcium sensor that directly regulates SNARE-mediated membrane fusion. J Cell Biol 191:187-197

Johnson SL, Marcotti W, Kros CJ (2005) Increase in efficiency and reduction in $\mathrm{Ca} 2+$ dependence of exocytosis during development of mouse inner hair cells. J Physiol 563:177-191

Johnson SL, Adelman JP, Marcotti W (2007) Genetic deletion of SK2 channels in mouse inner hair cells prevents the developmental linearization in the $\mathrm{Ca} 2+$ dependence of exocytosis. J Physiol 583:631646

Johnson SL, Eckrich T, Kuhn S, Zampini V, Franz C, Ranatunga KM, Roberts TP, Masetto S, Knipper M, Kros CJ, Marcotti W (2011) Position-dependent patterning of spontaneous action potentials in immature cochlear inner hair cells. Nat Neurosci 14:711-717

Johnson SL, Kuhn S, Franz C, Ingham N, Furness DN, Knipper M, Steel KP, Adelman JP, Holley MC, Marcotti W (2013a) Presynaptic maturation in auditory hair cells requires a critical period of sensoryindependent spiking activity. Proc Natl Acad Sci U S A 110:8720 8725

Johnson SL, Wedemeyer C, Vetter DE, Adachi R, Holley MC, Elgoyhen AB, Marcotti W (2013b) Cholinergic efferent synaptic transmission regulates the maturation of auditory hair cell ribbon synapses. Open Biol 3:130163

Kamin D, Revelo NH, Rizzoli SO (2014) FM dye photo-oxidation as a tool for monitoring membrane recycling in inner hair cells Cousin MA, ed. PLoS ONE 9:e88353

Kantardzhieva AV, Peppi M, Lane WS, Sewell WF (2011) Protein composition of immunoprecipitated synaptic ribbons. J Proteome Res 11:1163-1174 
Kantardzhieva A, Liberman MC, Sewell WF (2013) Quantitative analysis of ribbons, vesicles, and cisterns at the cat inner hair cell synapse: correlations with spontaneous rate. J Comp Neurol 521:3260-3271

Katz E, Elgoyhen AB, Gómez-Casati ME, Knipper M, Vetter DE, Fuchs PA, Glowatzki E (2004) Developmental regulation of nicotinic synapses on cochlear inner hair cells. J Neurosci 24:7814-7820

Kazmierczak P, Müller U (2012) Sensing sound: molecules that orchestrate mechanotransduction by hair cells. Trends Neurosci 35:220 229

Keen EC, Hudspeth AJ (2006) Transfer characteristics of the hair cell's afferent synapse. Proc Natl Acad Sci U S A 103:5537-5542

Keyel PA, Thieman JR, Roth R, Erkan E, Everett ET, Watkins SC, Heuser JE, Traub LM (2008) The AP-2 adaptor beta2 appendage scaffolds alternate cargo endocytosis. Mol Biol Cell 19:5309-5326

Khimich D, Nouvian R, Pujol R, tom Dieck S, Egner A, Gundelfinger ED, Moser T (2005) Hair cell synaptic ribbons are essential for synchronous auditory signalling. Nature 434:889-894

Kiang NYS, Watanabe T, Thomas EC, Clark LF (1965) Discharge patterns of single fibers in the cat's auditory nerve. MIT, Cambridge

Kiang NY, Rho JM, Northrop CC, Liberman MC, Ryugo DK (1982) Hair-cell innervation by spiral ganglion cells in adult cats. Science 217:175-177

Kim S, Ko J, Shin H, Lee J-R, Lim C, Han J-H, Altrock WD, Garner CC, Gundelfinger ED, Premont RT, Kaang B-K, Kim E (2003) The GIT family of proteins forms multimers and associates with the presynaptic cytomatrix protein Piccolo. J Biol Chem 278:6291-6300

Kittel RJ, Wichmann C, Rasse TM, Fouquet W, Schmidt M, Schmid A, Wagh DA, Pawlu C, Kellner RR, Willig KI, Hell SW, Buchner E, Heckmann M, Sigrist SJ (2006) Bruchpilot promotes active zone assembly, $\mathrm{Ca}^{2+}$ channel clustering, and vesicle release. Science 312:1051-1054

Kittelmann M, Liewald JF, Hegermann J, Schultheis C, Brauner M, Steuer Costa W, Wabnig S, Eimer S, Gottschalk A (2013) In vivo synaptic recovery following optogenetic hyperstimulation. Proc Natl Acad Sci U S A 110:E3007-E3016

Klar TA, Jakobs S, Dyba M, Egner A, Hell SW (2000) Fluorescence microscopy with diffraction resolution barrier broken by stimulated emission. Proc Natl Acad Sci U S A 97:8206-8210

Knott G, Marchman H, Wall D, Lich B (2008) Serial section scanning electron microscopy of adult brain tissue using focused ion beam milling. J Neurosci 28:2959-2964

Köppl C (1997) Phase locking to high frequencies in the auditory nerve and cochlear nucleus magnocellularis of the barn owl, Tyto Alba. J Neurosci 17:3312

Kreshuk A, Straehle CN, Sommer C, Koethe U, Cantoni M, Knott G, Hamprecht FA (2011) Automated detection and segmentation of synaptic contacts in nearly isotropic serial electron microscopy images. PLoS ONE 6:e24899

Kros CJ, Ruppersberg JP, Rüsch A (1998) Expression of a potassium current in inner hair cells during development of hearing in mice. Nature 394:281-284

Leal-Ortiz S, Waites CL, Terry-Lorenzo R, Zamorano P, Gundelfinger ED, Garner CC (2008) Piccolo modulation of Synapsin1a dynamics regulates synaptic vesicle exocytosis. J Cell Biol 181: 831-846

Lelli A, Asai Y, Forge A, Holt JR, Géléoc GSG (2009) Tonotopic gradient in the developmental acquisition of sensory transduction in outer hair cells of the mouse cochlea. J Neurophysiol 101:2961-2973

Lenzi D, von Gersdorff H (2001) Structure suggests function: the case for synaptic ribbons as exocytotic nanomachines. Bioessays 23:831840

Lenzi D, Runyeon JW, Crum J, Ellisman MH, Roberts WM (1999) Synaptic vesicle populations in saccular hair cells reconstructed by electron tomography. J Neurosci 19:119-132
Lenzi D, Crum J, Ellisman MH, Roberts WM (2002) Depolarization redistributes synaptic membrane and creates a gradient of vesicles on the synaptic body at a ribbon synapse. Neuron 36:649-659

LeVay S (1973) Synaptic patterns in the visual cortex of the cat and monkey. Electron microscopy of golgi preparations. J Comp Neurol 150:53-85

Lewis RS, Hudspeth AJ (1983) Voltage- and ion-dependent conductances in solitary vertebrate hair cells. Nature 304:538-541

Li GL, Keen E, Andor-Ardó D, Hudspeth AJ, von Gersdorff H (2009) The unitary event underlying multiquantal EPSCs at a hair cell's ribbon synapse. J Neurosci 29:7558

Li G-L, Cho S, von Gersdorff H (2014) Phase-locking precision is enhanced by multiquantal release at an auditory hair cell ribbon synapse. Neuron 83:1404-1417

Liberman MC (1980) Morphological differences among radial afferent fibers in the cat cochlea: an electron-microscopic study of serial sections. Hear Res 3:45-63

Liberman M (1982a) Single-neuron labeling in the cat auditory nerve. Science 216:1239-1241

Liberman MC (1982b) The cochlear frequency map for the cat: labeling auditory-nerve fibers of known characteristic frequency. J Acoust Soc Am 72:1441-1449

Liberman MC, Kiang NY (1978) Acoustic trauma in cats. Cochlear pathology and auditory-nerve activity. Acta Otolaryngol Suppl 358:163

Liberman MC, Dodds LW, Pierce S (1990) Afferent and efferent innervation of the cat cochlea: quantitative analysis with light and electron microscopy. J Comp Neurol 301:443-460

Liberman LD, Wang H, Liberman MC (2011) Opposing gradients of ribbon size and AMPA receptor expression underlie sensitivity differences among cochlear-nerve/hair-cell synapses. J Neurosci 31: 801-808

Limbach C, Laue MM, Wang X, Hu B, Thiede N, Hultqvist G, Kilimann MW (2011) Molecular in situ topology of Aczonin/Piccolo and associated proteins at the mammalian neurotransmitter release site. Proc Natl Acad Sci U S A 108:E392-E401

Liu H, Pecka JL, Zhang Q, Soukup GA, Beisel KW, He DZZ (2014) Characterization of transcriptomes of cochlear inner and outer hair cells. J Neurosci 34:11085-11095

Longo-Guess C, Gagnon LH, Bergstrom DE, Johnson KR (2007) A missense mutation in the conserved $\mathrm{C} 2 \mathrm{~B}$ domain of otoferlin causes deafness in a new mouse model of DFNB9. Hear Res 234:21-28

Magupalli VG, Schwarz K, Alpadi K, Natarajan S, Seigel GM, Schmitz F (2008) Multiple RIBEYE-RIBEYE interactions create a dynamic scaffold for the formation of synaptic ribbons. J Neurosci 28: 7954-7967

Marcotti W (2004) A transiently expressed SK current sustains and modulates action potential activity in immature mouse inner hair cells. $\mathrm{J}$ Physiol 560:691-708

Martinez-Dunst C, Michaels RL, Fuchs PA (1997) Release sites and calcium channels in hair cells of the chick's cochlea. J Neurosci 17:9133

Matthews G, Fuchs P (2010) The diverse roles of ribbon synapses in sensory neurotransmission. Nat Rev Neurosci 11:812-822

Meller K, Breipohl W, Glees P (1968) The cytology of the developing molecular layer of mouse motor cortex. An electron microscopical and a Golgi impregnation study. Z Zellforsch Mikrosk Anat 86:171183

Merchan-Perez A, Liberman MC (1996) Ultrastructural differences among afferent synapses on cochlear hair cells: correlations with spontaneous discharge rate. J Comp Neurol 371:208-221

Meyer AC, Moser T (2010) Structure and function of cochlear afferent innervation. Curr Opin Otolaryngol Head Neck Surg 18:441-446 
Meyer AC, Frank T, Khimich D, Hoch G, Riedel D, Chapochnikov NM, Yarin YM, Harke B, Hell SW, Egner A, Moser T (2009) Tuning of synapse number, structure and function in the cochlea. Nat Neurosci $12: 444-453$

Miesenböck G, De Angelis DA, Rothman JE (1998) Visualizing secretion and synaptic transmission with $\mathrm{pH}$-sensitive green fluorescent proteins. Nature 394:192-195

Mikaelian D, Ruben RJ (1965) Development of hearing in the normal Cba-J mouse: correlation of physiological observations with behavioral responses and with cochlear anatomy. Acta Otolaryngol (Stockh) 59:451-461

Morgans CW (2000) Presynaptic proteins of ribbon synapses in the retina. Microsc Res Tech 50:141-150

Morgans CW, Brandstätter JH, Kellerman J, Betz H, Wässle H (1996) A SNARE complex containing syntaxin 3 is present in ribbon synapses of the retina. J Neurosci 16:6713

Moser T, Beutner D (2000) Kinetics of exocytosis and endocytosis at the cochlear inner hair cell afferent synapse of the mouse. Proc Natl Acad Sci U S A 97:883-888

Moser T, Brandt A, Lysakowski A (2006) Hair cell ribbon synapses. Cell Tissue Res 326:347-359

Mukherjee K, Yang X, Gerber SH, Kwon HB, Ho A, Castillo PE, Liu X, Südhof TC (2010) Piccolo and bassoon maintain synaptic vesicle clustering without directly participating in vesicle exocytosis. Proc Natl Acad Sci U S A 107:6504

Muresan V, Lyass A, Schnapp BJ (1999) The kinesin motor KIF3A is a component of the presynaptic ribbon in vertebrate photoreceptors. $\mathrm{J}$ Neurosci 19:1027-1037

Nagel G, Szellas T, Huhn W, Kateriya S, Adeishvili N, Berthold P, Ollig D, Hegemann P, Bamberg E (2003) Channelrhodopsin-2, a directly light-gated cation-selective membrane channel. Proc Natl Acad Sci U S A 100:13940

Neef A, Khimich D, Pirih P, Riedel D, Wolf F, Moser T (2007) Probing the mechanism of exocytosis at the hair cell ribbon synapse. J Neurosci 27:12933-12944

Neef J, Jung S, Wong AB, Reuter K, Pangrsic T, Chakrabarti R, Kugler S, Lenz C, Nouvian R, Boumil RM, Frankel WN, Wichmann C, Moser $\mathrm{T}$ (2014) Modes and regulation of endocytic membrane retrieval in mouse auditory hair cells. J Neurosci 34:705-716

Nouvian R, Neef J, Bulankina AV, Reisinger E, Pangršič T, Frank T, Sikorra S, Brose N, Binz T, Moser T (2011) Exocytosis at the hair cell ribbon synapse apparently operates without neuronal SNARE proteins. Nat Neurosci 14:411-413

Palmer AR, Russell IJ (1986) Phase-locking in the cochlear nerve of the guinea-pig and its relation to the receptor potential of inner haircells. Hear Res 24:1-15

Pan B, Géléoc GS, Asai Y, Horwitz GC, Kurima K, Ishikawa K, Kawashima Y, Griffith AJ, Holt JR (2013) TMC1 and TMC2 are components of the mechanotransduction channel in hair cells of the mammalian inner ear. Neuron 79:504-515

Pangršič T, Lasarow L, Reuter K, Takago H, Schwander M, Riedel D, Frank T, Tarantino LM, Bailey JS, Strenzke N, Brose N, Müller U, Reisinger E, Moser T (2010) Hearing requires otoferlin-dependent efficient replenishment of synaptic vesicles in hair cells. Nat Neurosci 13:869-876

Pangršič T, Reisinger E, Moser T (2012) Otoferlin: a multi-C2 domain protein essential for hearing. Trends Neurosci 35:671-680

Paradiesgarten A, Spoendlin H (1976) The unmyelinated nerve fibres of the cochlea. Acta Otolaryngol (Stockh) 82:157-164

Parsons TD, Sterling P (2003) Synaptic ribbon. Conveyor belt or safety belt? Neuron 37:379-382

Parsons TD, Lenzi D, Almers W, Roberts WM (1994) Calcium-triggered exocytosis and endocytosis in an isolated presynaptic cell: capacitance measurements in saccular hair cells. Neuron 13:875-883
Perkins RE, Morest DK (1975) A study of cochlear innervation patterns in cats and rats with the Golgi method and Nomarkski Optics. J Comp Neurol 163:129-158

Phillips GR, Huang JK, Wang Y, Tanaka H, Shapiro L, Zhang W, Shan WS, Arndt K, Frank M, Gordon RE, Gawinowicz MA, Zhao Y, Colman DR (2001) The presynaptic particle web: ultrastructure, composition, dissolution, and reconstitution. Neuron 32:63-77

Platzer J, Engel J, Schrott-Fischer A, Stephan K, Bova S, Chen H, Zheng H, Striessnig J (2000) Congenital deafness and sinoatrial node dysfunction in mice lacking class D L-type Ca2+ channels. Cell 102: 89-97

Pujol R, Lavigne-Rebillard M, Lenoir M (1998) Development of sensory and neural structures in the mammalian cochlea. In: Development of the auditory system, pp 146-192. Springer, New York

Ramakrishnan NA, Drescher MJ, Drescher DG (2009) Direct interaction of otoferlin with syntaxin 1A, SNAP-25, and the L-type voltagegated calcium channel Cav1.3. J Biol Chem 284:1364-1372

Ramakrishnan NA, Drescher MJ, Morley BJ, Kelley PM, Drescher DG (2014) Calcium regulates molecular interactions of otoferlin with SNARE proteins required for hair cell exocytosis. J Biol Chem 289(13):8750-8766

Regus-Leidig H, Ott C, Löhner M, Atorf J, Fuchs M, Sedmak T, Kremers J, Fejtová A, Gundelfinger ED, Brandstätter JH (2013) Identification and immunocytochemical characterization of Piccolino, a novel Piccolo splice variant selectively expressed at sensory ribbon synapses of the eye and ear. PLoS ONE 8:e70373

Regus-Leidig H, Fuchs M, Löhner M, Leist SR, Leal-Ortiz S, Chiodo VA, Hauswirth WW, Garner CC, Brandstätter JH (2014) In vivo knockdown of Piccolino disrupts presynaptic ribbon morphology in mouse photoreceptor synapses. Front Cell Neurosci 8:259

Reisinger E, Bresee C, Neef J, Nair R, Reuter K, Bulankina A, Nouvian R, Koch M, Bückers J, Kastrup L, Roux I, Petit C, Hell SW, Brose N, Rhee J-S, Kügler S, Brigande JV, Moser T (2011) Probing the functional equivalence of otoferlin and synaptotagmin 1 in exocytosis. J Neurosci 31:4886-4895

Revelo NH, Kamin D, Truckenbrodt S, Wong AB, Reuter-Jessen K, Reisinger E, Moser T, Rizzoli SO (2014) A new probe for superresolution imaging of membranes elucidates trafficking pathways. $\mathrm{J}$ Cell Biol 205:591-606

Roberts WM, Jacobs RA, Hudspeth AJ (1990) Colocalization of ion channels involved in frequency selectivity and synaptic transmission at presynaptic active zones of hair cells. J Neurosci 10:3664-3684

Rodríguez-Ballesteros M et al (2008) A multicenter study on the prevalence and spectrum of mutations in the otoferlin gene (OTOF) in subjects with nonsyndromic hearing impairment and auditory neuropathy. Hum Mutat 29:823-831

Rose JE, Brugge JF, Anderson DJ, Hind JE (1967) Phase-locked response to low-frequency tones in single auditory nerve fibers of the squirrel monkey. J Neurophysiol 30:769-793

Rosenmund C, Stevens CF (1996) Definition of the readily releasable pool of vesicles at hippocampal synapses. Neuron 16:1197-1207

Roux I, Safieddine S, Nouvian R, Grati M, Simmler M-C, Bahloul A, Perfettini I, Le Gall M, Rostaing P, Hamard G, Triller A, Avan P, Moser T, Petit C (2006) Otoferlin, defective in a human deafness form, is essential for exocytosis at the auditory ribbon synapse. Cell 127:277-289

Roux I, Hosie S, Johnson SL, Bahloul A, Cayet N, Nouaille S, Kros CJ, Petit C, Safieddine S (2009) Myosin VI is required for the proper maturation and function of inner hair cell ribbon synapses. Hum Mol Genet 18:4615-4628

Rutherford MA, Pangršič T (2012) Molecular anatomy and physiology of exocytosis in sensory hair cells. Cell Calcium 52:327-337

Rutherford MA, Roberts WM (2006) Frequency selectivity of synaptic exocytosis in frog saccular hair cells. Proc Natl Acad Sci U S A 103: 2898 
Rutherford MA, Chapochnikov NM, Moser T (2012) Spike encoding of neurotransmitter release timing by spiral ganglion neurons of the cochlea. J Neurosci 32:4773-4789

Ryugo DK, Rouiller EM (1988) Central projections of intracellularly labeled auditory nerve fibers in cats: morphometric correlations with physiological properties. J Comp Neurol 271:130-142

Safieddine S, Wenthold RJ (1999) SNARE complex at the ribbon synapses of cochlear hair cells: analysis of synaptic vesicle- and synaptic membrane-associated proteins. Eur J Neurosci 11:803-812

Safieddine S, El-Amraoui A, Petit C (2012) The auditory hair cell ribbon synapse: from assembly to function. Annu Rev Neurosci 35:509528

Saito K (1990) Freeze-fracture organization of hair cell synapses in the sensory epithelium of guinea pig organ of Corti. J Electron Microsc Technol 15:173-186

Schiavo G, Benfenati F, Poulain B, Rossetto O, Polverino de Laureto P, DasGupta BR, Montecucco C (1992) Tetanus and botulinum-B neurotoxins block neurotransmitter release by proteolytic cleavage of synaptobrevin. Nature 359:832-835

Schiavo G, Matteoli M, Montecucco C (2000) Neurotoxins affecting neuroexocytosis. Physiol Rev 80:717-766

Schmitz F (2009) The making of synaptic ribbons: how they are built and what they do. Neuroscientist 15:611-624

Schmitz F, Königstorfer A, Südhof TC (2000) RIBEYE, a component of synaptic ribbons: a protein's journey through evolution provides insight into synaptic ribbon function. Neuron 28:857-872

Schnee ME, Lawton DM, Furness DN, Benke TA, Ricci AJ (2005) Auditory hair cell-afferent fiber synapses are specialized to operate at their best frequencies. Neuron 47:243-254

Schwander M, Sczaniecka A, Grillet N, Bailey JS, Avenarius M, Najmabadi H, Steffy BM, Federe GC, Lagler EA, Banan R, Hice R, Grabowski-Boase L, Keithley EM, Ryan AF, Housley GD, Wiltshire T, Smith RJH, Tarantino LM, Müller U (2007) A forward genetics screen in mice identifies recessive deafness traits and reveals that pejvakin is essential for outer hair cell function. J Neurosci 27:2163-2175

Schwarz K, Natarajan S, Kassas N, Vitale N, Schmitz F (2011) The synaptic ribbon is a site of phosphatidic acid generation in ribbon synapses. J Neurosci 31:15996-16011

Sendin G, Bulankina AV, Riedel D, Moser T (2007) Maturation of ribbon synapses in hair cells is driven by thyroid hormone. J Neurosci 27 : 3163-3173

Sendin G, Bourien J, Rassendren F, Puel J-L, Nouvian R (2014) Spatiotemporal pattern of action potential firing in developing inner hair cells of the mouse cochlea. Proc Natl Acad Sci U S A 111: 1999-2004

Sheets L, Hagen MW, Nicolson T (2014) Characterization of Ribeye subunits in zebrafish hair cells reveals that exogenous Ribeye Bdomain and CtBP1 localize to the basal ends of synaptic ribbons. PLoS ONE 9:e107256

Siegel JH (1992) Spontaneous synaptic potentials from afferent terminals in the guinea pig cochlea. Hear Res 59:85-92

Siegel JH, Brownell WE (1986) Synaptic and Golgi membrane recycling in cochlear hair cells. J Neurocytol 15:311-328

Sienknecht UJ, Köppl C, Fritzsch B (2014) Evolution and development of hair cell polarity and efferent function in the inner ear. Brain Behav Evol 83:150-161

Siksou L, Rostaing P, Lechaire J-P, Boudier T, Ohtsuka T, Fejtová A, Kao H-T, Greengard P, Gundelfinger ED, Triller A, Marty S (2007) Three-dimensional architecture of presynaptic terminal cytomatrix. J Neurosci 27:6868-6877

Siksou L, Varoqueaux F, Pascual O, Triller A, Brose N, Marty S (2009) A common molecular basis for membrane docking and functional priming of synaptic vesicles. Eur J Neurosci 30:49-56

Simmons DD (2002) Development of the inner ear efferent system across vertebrate species. J Neurobiol 53:228-250
Simmons DD, Moulding HD, Zee D (1996) Olivocochlear innervation of inner and outer hair cells during postnatal maturation: an immunocytochemical study. Brain Res Dev Brain Res 95:213-226

Sjostrand FS (1953) The ultrastructure of the innersegments of the retinal rods of the guinea pig eye as revealed by electron microscopy. J Cell Physiol 42:45-70

Sjostrand FS (1958) Ultrastructure of retinal rod synapses of the guinea pig eye as revealed by three-dimensional reconstructions from serial sections. J Ultrastruct Res 2:122-170

Slepecky N, Chamberlain SC (1985) Immunoelectron microscopic and immunofluorescent localization of cytoskeletal and muscle-like contractile proteins in inner ear sensory hair cells. Hear Res 20:245-260

Smith CA, Sjostrand FS (1961) Structure of the nerve endings on the external hair cells of the guinea pig cochlea as studied by serial sections. J Ultrastruct Res 5:523-556

Smith CA, Sjöstrand FS (1961) A synaptic structure in the hair cells of the guinea pig cochlea. J Ultrastruct Res 5:184-192

Snellman J, Mehta B, Babai N, Bartoletti TM, Akmentin W, Francis A, Matthews G, Thoreson W, Zenisek D (2011) Acute destruction of the synaptic ribbon reveals a role for the ribbon in vesicle priming. Nat Neurosci 14:1135-1141

Sobkowicz HM, Rose JE, Scott GE, Slapnick SM (1982) Ribbon synapses in the developing intact and cultured organ of Corti in the mouse. J Neurosci 2:942

Spiwoks-Becker I, Lamberti R, Tom Dieck S, Spessert R (2013) Evidence for synergistic and complementary roles of bassoon and darkness in organizing the ribbon synapse. Neuroscience 236:149 159

Spoendlin H (1969) Innervation patterns in the organ of corti of the cat. Acta Otolaryngol (Stockh) 67:239-254

Spoendlin H (1972) Innervation densities of the cochlea. Acta Otolaryngol (Stockh) 73:235-248

Spoendlin H (1975) Neuroanatomical basis of cochlear coding mechanisms. Audiology 14:383-407

Spoendlin H (1979) Sensory neural organization of the cochlea. J Laryngol Otol 93:853-877

Starr PA, Sewell WF (1991) Neurotransmitter release from hair cells and its blockade by glutamate-receptor antagonists. Hear Res 52:23-41

Steyger PS, Furness DN, Hackney CM, Richardson GP (1989) Tubulin and microtubules in cochlear hair cells: comparative immunocytochemistry and ultrastructure. Hear Res 42:1-16

Strenzke N, Chanda S, Kopp-Scheinpflug C, Khimich D, Reim K, Bulankina AV, Neef A, Wolf F, Brose N, Xu-Friedman MA, Moser T (2009) Complexin-I is required for high-fidelity transmission at the endbulb of held auditory synapse. J Neurosci 29:79918004

Südhof TC (2012) The presynaptic active zone. Neuron 75:11-25

Szarama KB, Gavara N, Petralia RS, Kelley MW, Chadwick RS (2012) Cytoskeletal changes in actin and microtubules underlie the developing surface mechanical properties of sensory and supporting cells in the mouse cochlea. Development 139:2187-2197

Szule JA, Harlow ML, Jung JH, De-Miguel FF, Marshall RM, McMahan UJ (2012) Regulation of synaptic vesicle docking by different classes of macromolecules in active zone material. PLoS ONE 7:e33333

Tom Dieck S, Altrock WD, Kessels MM, Qualmann B, Regus H, Brauner D, Fejtová A, Bracko O, Gundelfinger ED, Brandstätter JH (2005) Molecular dissection of the photoreceptor ribbon synapse: physical interaction of bassoon and RIBEYE is essential for the assembly of the ribbon complex. J Cell Biol 168:825-836

Tritsch NX, Yi E, Gale JE, Glowatzki E, Bergles DE (2007) The origin of spontaneous activity in the developing auditory system. Nature 450 : $50-55$

Tritsch NX, Rodríguez-Contreras A, Crins TTH, Wang HC, Borst JGG, Bergles DE (2010) Calcium action potentials in hair cells pattern auditory neuron activity before hearing onset. Nat Neurosci 13: $1050-1052$ 
Tucker T, Fettiplace R (1995) Confocal imaging of calcium microdomains and calcium extrusion in turtle hair cells. Neuron 15:1323 1335

Usukura J, Yamada E (1987) Ultrastructure of the synaptic ribbons in photoreceptor cells of Rana catesbeiana; revealed by freezeetching and freeze-substitution. Cell Tissue Res 247:483-488

Uthaiah RC, Hudspeth AJ (2010) Molecular anatomy of the hair cell's ribbon synapse. J Neurosci 30:12387-12399

Varga R, Avenarius MR, Kelley PM, Keats BJ, Berlin CI, Hood LJ, Morlet TG, Brashears SM, Starr A, Cohn ES, Smith RJH, Kimberling WJ (2006) OTOF mutations revealed by genetic analysis of hearing loss families including a potential temperature sensitive auditory neuropathy allele. J Med Genet 43:576-581

Vogl C, Cooper BH, Neef J, Wojcik SM, Reim K, Reisinger E, Brose N, Rhee JS, Moser T, Wichmann C (2015) Unconventional molecular regulation of synaptic vesicle replenishment in cochlear inner hair cells. J Cell Science, in press.

Vollrath L, Spiwoks-Becker I (1996) Plasticity of retinal ribbon synapses. Microsc Res Tech 35:472-487

Von Gersdorff H, Vardi E, Matthews G, Sterling P (1996) Evidence that vesicles on the synaptic ribbon of retinal bipolar neurons can be rapidly released. Neuron 16:1221-1227

Von Kriegstein K, Schmitz F (2003) The expression pattern and assembly profile of synaptic membrane proteins in ribbon synapses of the developing mouse retina. Cell Tissue Res 311:159-173

Vranceanu F, Perkins GA, Terada M, Chidavaenzi RL, Ellisman MH, Lysakowski A (2012) Striated organelle, a cytoskeletal structure positioned to modulate hair-cell transduction. Proc Natl Acad Sci U S A 109:4473-4478

Vrensen G, Cardozo JN, Müller L, van der Want J (1980) The presynaptic grid: a new approach. Brain Res 184:23-40

Wagh DA, Rasse TM, Asan E, Hofbauer A, Schwenkert I, Dürrbeck H, Buchner S, Dabauvalle MC, Schmidt M, Qin G et al (2006) Bruchpilot, a protein with homology to ELKS/CAST, is required for structural integrity and function of synaptic active zones in Drosophila. Neuron 49:833-844

Waguespack J, Salles FT, Kachar B, Ricci AJ (2007) Stepwise morphological and functional maturation of mechanotransduction in rat outer hair cells. J Neurosci 27:13890-13902

Wahl S, Katiyar R, Schmitz F (2013) A local, periactive zone endocytic machinery at photoreceptor synapses in close vicinity to synaptic ribbons. J Neurosci 33:10278-10300

Waites CL, Leal-Ortiz SA, Andlauer TFM, Sigrist SJ, Garner CC (2011) Piccolo regulates the dynamic assembly of presynaptic F-actin. J Neurosci 31:14250-14263

Waites CL, Leal-Ortiz SA, Okerlund N, Dalke H, Fejtova A, Altrock WD, Gundelfinger ED, Garner CC (2013) Bassoon and Piccolo maintain synapse integrity by regulating protein ubiquitination and degradation. EMBO J 32:954-969

Wan L, Almers W, Chen W (2005) Two ribeye genes in teleosts: the role of Ribeye in ribbon formation and bipolar cell development. J Neurosci 25:941-949

Wang Y, Okamoto M, Schmitz F, Hofmann K, Sudhof TC (1997) Rim is a putative Rab3 effector in regulating synaptic-vesicle fusion. Nature 388:593-598
Wang X, Kibschull M, Laue MM, Lichte B, Petrasch-Parwez E, Kilimann MW (1999) Aczonin, a 550-Kd putative scaffolding protein of presynaptic active zones, shares homology regions with rim and bassoon and binds profilin. J Cell Biol 147:151-162

Wang L-Y, Fedchyshyn MJ, Yang Y-M (2009) Action potential evoked transmitter release in central synapses: insights from the developing calyx of held. Mol Brain 2:36

Watanabe S, Liu Q, Davis MW, Hollopeter G, Thomas N, Jorgensen NB, Jorgensen EM (2013a) Ultrafast endocytosis at Caenorhabditis elegans neuromuscular junctions. eLife 2:e0723

Watanabe S, Rost BR, Camacho-Pérez M, Davis MW, Söhl-Kielczynski B, Rosenmund C, Jorgensen EM (2013b) Ultrafast endocytosis at mouse hippocampal synapses. Nature 504:242-247

White EL, Rock MP (1980) Three-dimensional aspects and synaptic relationships of a Golgi-impregnated spiny stellate cell reconstructed from serial thin sections. J Neurocytol 9:615-636

Wichmann C, Sigrist SJ (2010) The active zone T-bar-a plasticity module? J Neurogenet 24:133-145

Wong AB, Jing Z, Rutherford MA, Frank T, Strenzke N, Moser T (2013) Concurrent maturation of inner hair cell synaptic $\mathrm{Ca} 2+$ influx and auditory nerve spontaneous activity around hearing onset in mice. J Neurosci 33:10661-10666

Wong AB, Rutherford MA, Gabrielaitis M, Pangrsic T, Göttfert F, Frank T, Michanski S, Hell S, Wolf F, Wichmann C, Moser T (2014) Developmental refinement of hair cell synapses tightens the coupling of Ca2+ influx to exocytosis. EMBO J 33:247-264

Yasunaga S, Grati M, Cohen-Salmon M, El-Amraoui A, Mustapha M, Salem N, El-Zir E, Loiselet J, Petit C (1999) A mutation in OTOF, encoding otoferlin, a FER-1-like protein, causes DFNB9, a nonsyndromic form of deafness. Nat Genet 21:363-369

Yin Y, Liberman LD, Maison SF, Liberman MC (2014) Olivocochlear innervation maintains the normal modiolar-pillar and habenularcuticular gradients in cochlear synaptic morphology. J Assoc Res Otolaryngol 15:571-583

Zampini V, Johnson SL, Franz C, Lawrence ND, Münkner S, Engel J, Knipper M, Magistretti J, Masetto S, Marcotti W (2010) Elementary properties of $\mathrm{CaV} 1.3 \mathrm{Ca}(2+)$ channels expressed in mouse cochlear inner hair cells. J Physiol 588:187-199

Zampini V, Johnson SL, Franz C, Knipper M, Holley MC, Magistretti J, Masetto S, Marcotti W (2013) Burst activity and ultrafast activation kinetics of $\mathrm{CaV} 1.3 \mathrm{Ca} 2+$ channels support presynaptic activity in adult gerbil hair cell ribbon synapses. J Physiol 591:3811-3820

Zenisek D, Steyer JA, Almers W (2000) Transport, capture and exocytosis of single synaptic vesicles at active zones. Nature 406:849-854

Zenisek D, Davila V, Wan L, Almers W (2003) Imaging calcium entry sites and ribbon structures in two presynaptic cells. J Neurosci 23: $2538-2548$

Zhai RG, Bellen HJ (2004) The architecture of the active zone in the presynaptic nerve terminal. Physiology 19:262-270

Zhu Y, Xu J, Heinemann SF (2009) Two pathways of synaptic vesicle retrieval revealed by single-vesicle imaging. Neuron 61:397-411

Zine EA, Romand R (1993) Expression of alpha-actinin in the stereocilia of hair cells of the inner ear: immunohistochemical localization. Neuroreport 4:1350-1352 